\title{
Detection of planktonic coenzyme factor 430 in a freshwater lake: small-scale analysis for probing archaeal methanogenesis
}

\author{
Atsushi Urai ${ }^{1,2^{*}}$ (D), Makoto Matsushita ${ }^{1,3}$, Ho-Dong Park ${ }^{4}$, Hiroyuki Imachi ${ }^{5}$ (D) Miyuki Ogawara ${ }^{5}$,

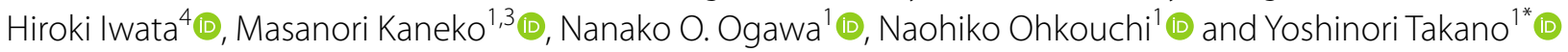

\begin{abstract}
We present the first data describing molecular evidence of planktonic coenzyme factor 430 (hereafter referred to as F430), a key signature of methanogenic archaea, obtained from a water column sample in a freshwater lake in Japan. We report concentrations of native F430 ranging from 6.8-35 × 10 femto mol g-wet $^{-1}$ and $8.5-86 \times 10^{2}$ femto mol $\mathrm{g}$ - wet $^{-1}$ in the water column and core-top sediment, respectively. Among these profiles, the epimer F430 of the deactivated chemical formula was very low overall in both planktonic and benthic environments. Small subunit (SSU) rRNA gene sequencing revealed that the planktonic microbial community was clearly different from that of the benthic sediment. Planktonic cyanobacteria (e.g., Microcystis) were predominant in the water column, whereas a wide variety of bacteria and archaea, including methanogens (e.g., Methanobacterium, Methanoregula, Methanothrix, Methanosarcina, and Methanocella), were observed in the core-top sediment. These results suggest that the planktonic cyanobacterial community may be rapidly degraded at the water-sediment interface driven by activated benthic microbial heterotrophic processes.
\end{abstract}

Keywords: Planktonic methanogen, Coenzyme F430, mcrA, Lake Suwa, Surface hydrosphere

\section{Introduction}

Freshwater lakes are considered one of the main natural sources of methane $\left(\mathrm{CH}_{4}\right)$ emissions in terrestrial environments, accounting for $6-16 \%$ of $\mathrm{CH}_{4}$ originating from natural sources (e.g., Bastviken et al. 2004; Cole et al. 2007; Holgerson and Raymond 2016; Günthel et al. 2019). The major $\mathrm{CH}_{4}$ fraction released from freshwater lakes is produced by methanogenic archaea in anoxic sediments, and this is the terminal step of organic matter decomposition (e.g., Zepp Falz et al. 1999; Chan et al. 2005; Thauer et al. 2008; Conrad 2009; Borrel et al. 2011; Bukin et al. 2018). Among these biogeochemical processes, heterotrophic

\footnotetext{
*Correspondence: uraia@jamstec.go.jp; takano@jamstec.go.jp

${ }^{1}$ Biogeochemistry Research Center (BGC), Japan Agency for Marine-Earth

Science and Technology (JAMSTEC), Yokosuka, Japan

Full list of author information is available at the end of the article
}

microbes degrade organic matter into $\mathrm{H}_{2}, \mathrm{CO}_{2}$, acetate, and methylated compounds, which are then adopted as the principal substrates for hydrogenotrophic, aceticlastic, or methylotrophic methanogenic pathways by methanogenic archaea. The $\mathrm{CH}_{4}$ occurring in anoxic sediments then diffuses into the atmosphere or is oxidized via anaerobic or aerobic microbial processes in the lacustrine water column (e.g., Bastviken et al. 2002; Thauer et al. 2008; Kojima et al. 2014; Deutzmann et al. 2014; Donis et al. 2017; Iwata et al. 2018).

To date, biogeochemical evidence of $\mathrm{CH}_{4}$ accumulation in oxygen-saturated freshwater and marine environments, commonly known as the methane paradox, has emerged (e.g., Repeta et al. 2016; Fernández et al. 2016; Tang et al. 2016; Sasakawa et al. 2008; Günthel et al. 2020). Three main hypotheses have been proposed to explain this enigmatic phenomenon: (1) methanogenesis by methanogenic archaea in anoxic microenvironments, 
such as detritus or animal guts (e.g., Oremland 1979; Burke et al. 1983; de Angelis and Lee 1994; Schmale et al. 2018; Wäge et al. 2020); (2) release of $\mathrm{CH}_{4}$ as a byproduct of the bacterial decomposition of potential precursors (e.g., methylphosphonate and dimethylsulfoniopropionate) under aerobic conditions (e.g., Damm et al. 2010; Wang et al. 2017; Khatun et al. 2019); and (3) methanogenesis by methanogenic archaea associated with photoautotrophic consortia in lacustrine environments (e.g., Grossart et al. 2011; McGinnis et al. 2015; Li et al. 2021). In addition to the abovementioned sources, we note the other origins of seep methane derived from deep terrestrial and/or oceanic sources along with some geological factors (e.g., Milkov and Sassen 2002; Naudts et al. 2006; Ritt et al. 2010; Valentine 2011 and the literature therein).

Within the context of planktonic methane production, Grossart et al. (2011) reported the coexistence of planktonic methanogen and cyanobacteria in the water column of an oligotrophic lake (Lake Stechlim, Germany) based on molecular analyses targeting the small subunit (SSU) rRNA gene and the methyl coenzyme $\mathrm{M}$ reductase A gene $(m c r A)$ (cf. methyl coenzyme $M$ reductase, McGinnis et al. 2015). It has been suggested that these cyanobacterial blooms may stimulate benthic $\mathrm{CH}_{4}$ production in sediment by increasing the supply of organic matter (Wang et al. 2006; Yan et al. 2017). In addition, Bižić et al. (2020) demonstrated $\mathrm{CH}_{4}$ production via pure cultures of cyanobacteria living in marine, freshwater, and terrestrial environments. Although it has been suggested that certain versatile methanogenic archaea thrive in anoxic microenvironments within planktonic cyanobacterial consortia (Batista et al. 2019) and/or in the interior of floating fecal pellets (Wäge et al. 2020), the entire $\mathrm{CH}_{4}$ production process in water column environments remains unclear.

To elucidate enigmatic planktonic methane biogeochemistry, we applied a new tool, namely, archaeal methanogen-specific coenzyme factor 430 (F430), with ultrasmall-scale approaches (e.g., Takano et al. 2013; Kaneko et al. 2014, 2016). F430 is a hydrocorphinoid nickel complex and is the prosthetic group of methyl coenzyme $M$ reductase, which catalyzes the final step of all methanogenesis pathways (e.g., Diekert et al. 1981; Thauer et al. 2008). F430 quantification indicates the ongoing activities of methanogenic archaea via rapid decomposition into its relic forms after the death of these archaea (e.g., Inagaki et al. 2015; Urai et al. 2021). To our knowledge, this is the first study to report the planktonic F430 concentration in a freshwater lake environment. Molecular SSU rRNA and mcrA gene analyses were also performed to assess the microbial community structure in both planktonic and benthic prokaryotic habitats.

\section{Materials and methods}

\subsection{Geological setting of Lake Suwa}

Lake Suwa is located in Nagano Prefecture in the central part of Honshu Island, Japan, on the Itoigawa-Shizuoka tectonic line (Fig. 1). The lake exhibits a surface area of $13.3 \mathrm{~km}^{2}$. The mean and maximum depths are 4.3 and $6.4 \mathrm{~m}$, respectively, with a water catchment area of 513 $\mathrm{km}^{2}$. The lake is a typical Japanese eutrophic lake affected by anthropogenic impacts originating from nearby cities,
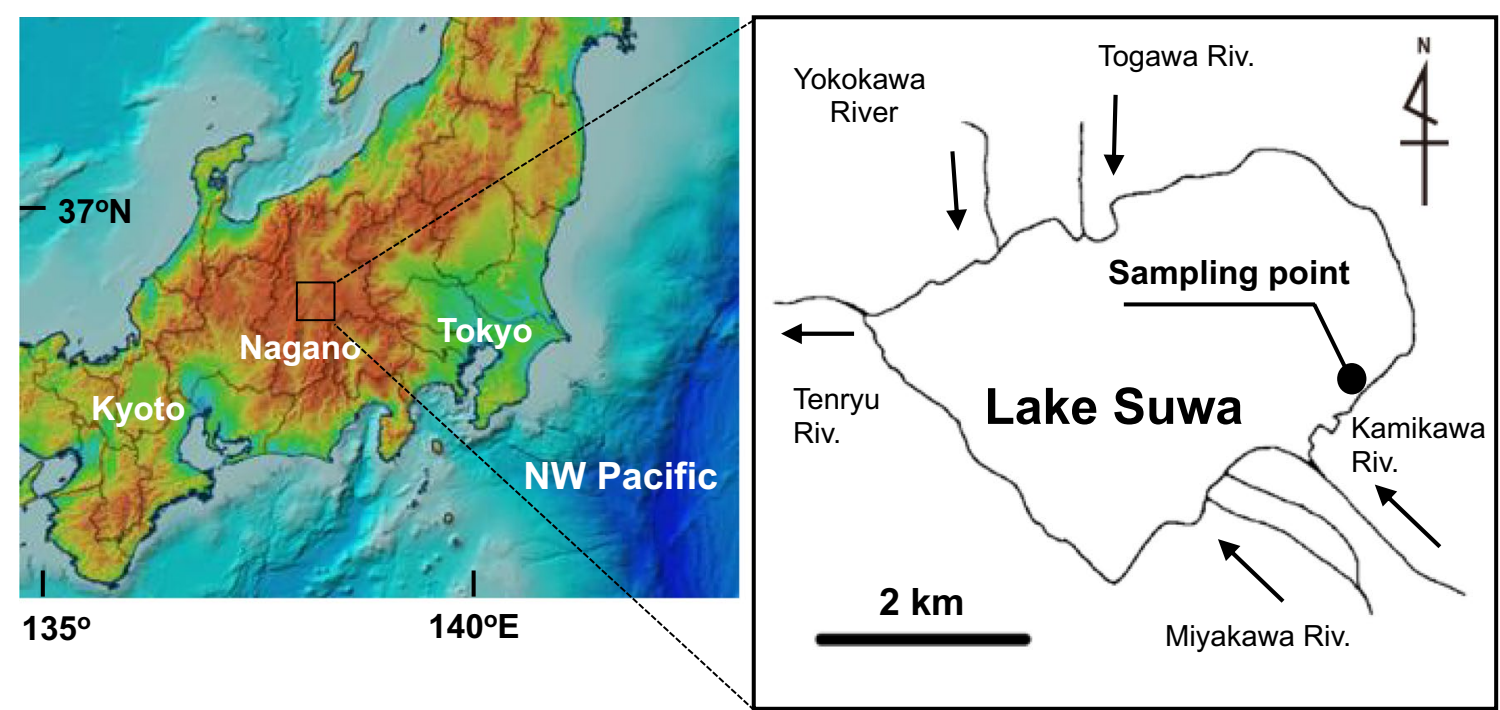

Fig. 1 Map of the study site location. Lake Suwa is located in the central part of Honshu Island, Japan $\left(36^{\circ} 2^{\prime} 46.92^{\prime \prime} \mathrm{N}, 138^{\circ} 6^{\prime} 30.94^{\prime \prime} \mathrm{E}\right)$. Samples were collected along the southeastern shore of Lake Suwa 
despite being surrounded by mountains. The lake attains a high sedimentation rate $\left(\sim 1 \mathrm{~cm} \mathrm{year}^{-1}\right)$ of organic-rich sediments (e.g., Nakazato et al. 1998; Suwa Construction Office 2019). In addition, cyanobacterial blooms, particularly those caused by Microcystis spp., have regularly occurred during the summer since the 1970s (Park et al. 1993, 1998; Watanabe et al. 2012). In an earlier study, we confirmed active $\mathrm{CH}_{4}$ emissions derived from the surface sediments of Lake Suwa (Iwata et al. 2020; Additional file 1: Movie S1).

\subsection{Sampling procedure for water, planktonic microbes, and sediment}

Samples were collected along the southeast shore of the lake $\left(36^{\circ} 2^{\prime} 46.92^{\prime \prime} \mathrm{N}, 138^{\circ} 6^{\prime} 30.94^{\prime \prime} \mathrm{E}\right.$; Fig. 2a) at a water depth of $1.8 \mathrm{~m}$ on September 28, 2018, and June 29, 2019. The water temperature and dissolved oxygen (DO) concentration were measured on-site at each depth with a DO meter (HQ-30D; Hach, Loveland, CO, USA). Lake water was collected in serum vials to measure the dissolved $\mathrm{CH}_{4}$ concentration, while cyanobacteria floating on the surface (Fig. 2b, c) were collected with a plankton net $(10-\mu \mathrm{m}$ mesh) and placed in polypropylene bottles (Fig. 2d). Benthic sediment was collected at depths of $0-10 \mathrm{~cm}$ in September 2018 and at depths of $0-3 \mathrm{~cm}$ in June 2019 with a gravity core sampler (50-cm long, 4-cm diameter) (Fig. 2e). Planktonic cyanobacteria and benthic sediment samples were preserved in an ice box and transported to the laboratory, where they were frozen and stored at $-30{ }^{\circ} \mathrm{C}$. The cyanobacterial samples were microscopically observed (PX-51; Olympus, Tokyo, Japan).

\subsection{Analytical procedures}

\subsubsection{Measurement of dissolved $\mathrm{CH}_{4}$}

The concentration of dissolved $\mathrm{CH}_{4}$ in the sampled lake water was analyzed on June 27 and September 28, 2018, and on June 28, August 29, and October 10, 2019, according to previously described methods (Itoh et al. 2015). Lake water was collected in $30-\mathrm{mL}$ vials from several depths $(0,10,50,100,130,150$, and $160 \mathrm{~cm})$ with syringes and tubes attached to a pier. $\mathrm{CH}_{4}$ was quantified using a gas chromatograph with a flame ionization detector (GC-14B; Shimadzu, Kyoto, Japan) and a packed column (Porapack-Q, 80/100 mesh, $1.5 \mathrm{~m} \times 3.0 \mathrm{~mm}$ inner diameter (i.d.); GL Sciences, Tokyo, Japan). The concentration of dissolved $\mathrm{CH}_{4}$ was calculated with the ideal gas law and Bunsen solubility coefficient (Magen et al. 2014).

\subsubsection{Extraction of 4430 by wet chemistry}

F430 analysis was performed according to a previously described method (Takano et al. 2013; Kaneko et al. 2014). In summary, F430 was extracted from planktonic cyanobacteria and benthic core-top sediments by using $1 \%$ formic acid under ultrasonication for $30 \mathrm{~min}$ on ice and centrifugation $\left(10,000 \mathrm{~g} ; 30 \mathrm{~min} ; 4^{\circ} \mathrm{C}\right)$. The supernatant was then recovered, and this step was repeated three times. The combined supernatants were introduced into an anion-exchange column (Q Sepharose; GE Healthcare, IL, USA) equilibrated with $50 \mathrm{mM}$ Tris- $\mathrm{HCl}(\mathrm{pH} 7.5)$ and washed with deionized water before use. The recovered eluent was introduced into a $\mathrm{C}_{18}$ SPE column (Sep-Pack; Waters, MA, USA) equilibrated with methanol and conditioned with $1 \%$ formic acid. F430 was eluted with methanol and converted into F430 methyl ester (F430M) via derivatization with $\mathrm{BF}_{3}$-methanol $\left(40{ }^{\circ} \mathrm{C} ; 3.5 \mathrm{~h}\right)$ before extraction with dichloromethane. To remove the organic matrix, the F430M fraction extracted from the samples was purified via silica gel chromatography (Kaneko et al. 2016). This pretreatment eliminates any potential analytical artifacts that may affect ultrasmall-scale analyses ( femto mol; e.g., Kaneko et al. 2014; Inagaki et al. 2015; Isaji et al. 2020) of tetrapyrrole compounds through chromatographic separation, which may induce ion suppression and enhancement effects in liquid chromatography/ electrospray ionization-mass spectrometry (LC/ESI-MS).

\subsubsection{Qualification and quantification of F430 using LC/ ESI-MS}

The concentration of extracted F430M was determined via high-performance liquid chromatography/electrospray ionization-mass spectrometry (HPLC/ESI-MS/ MS; 1260 Infinity II LC System coupled to a 6490 Triple Quadrupole LC-MS system with an Agilent jet stream; Agilent Technologies, CA, USA) in positive ion mode. Chromatographic separation was performed with a ZORBAX Eclipse XDB-C18 column $(0.5 \times 150 \mathrm{~mm}$; $5 \mu \mathrm{m}$, Agilent Technologies). Multiple reaction monitoring (MRM) analysis was performed at a fragmentor voltage of $380 \mathrm{~V}$ and a collision energy of $70 \mathrm{~V}$. The F430M product ion was set to $m / z$ 844.3. The mobile phases included $10 \mathrm{mM}$ ammonium acetate with $1 \%$ acetonitrile (A) and acetonitrile (B) at a flow rate of $16 \mu \mathrm{L} \mathrm{min}{ }^{-1}$ and the following gradient: $0 \% \mathrm{~B}, 30 \% \mathrm{~B}$ after $3 \mathrm{~min}$, and $90 \% \mathrm{~B}$ after 90 min (Mayr et al. 2008). The F430M concentration was determined with an external F430M standard (Kaneko et al. 2014, 2016).

\subsubsection{SSU rRNA gene tag sequencing}

Total DNA was extracted from the cyanobacteria and benthic sediments collected in September 2018 using a Plant Genomic DNA Extraction Miniprep System (Viogene, Taipei, Taiwan) and a DNeasy Power Soil Kit (Qiagen, CA, USA), respectively, which were selected to achieve the most efficient DNA extraction from these samples. The concentration of the extracted DNA was 

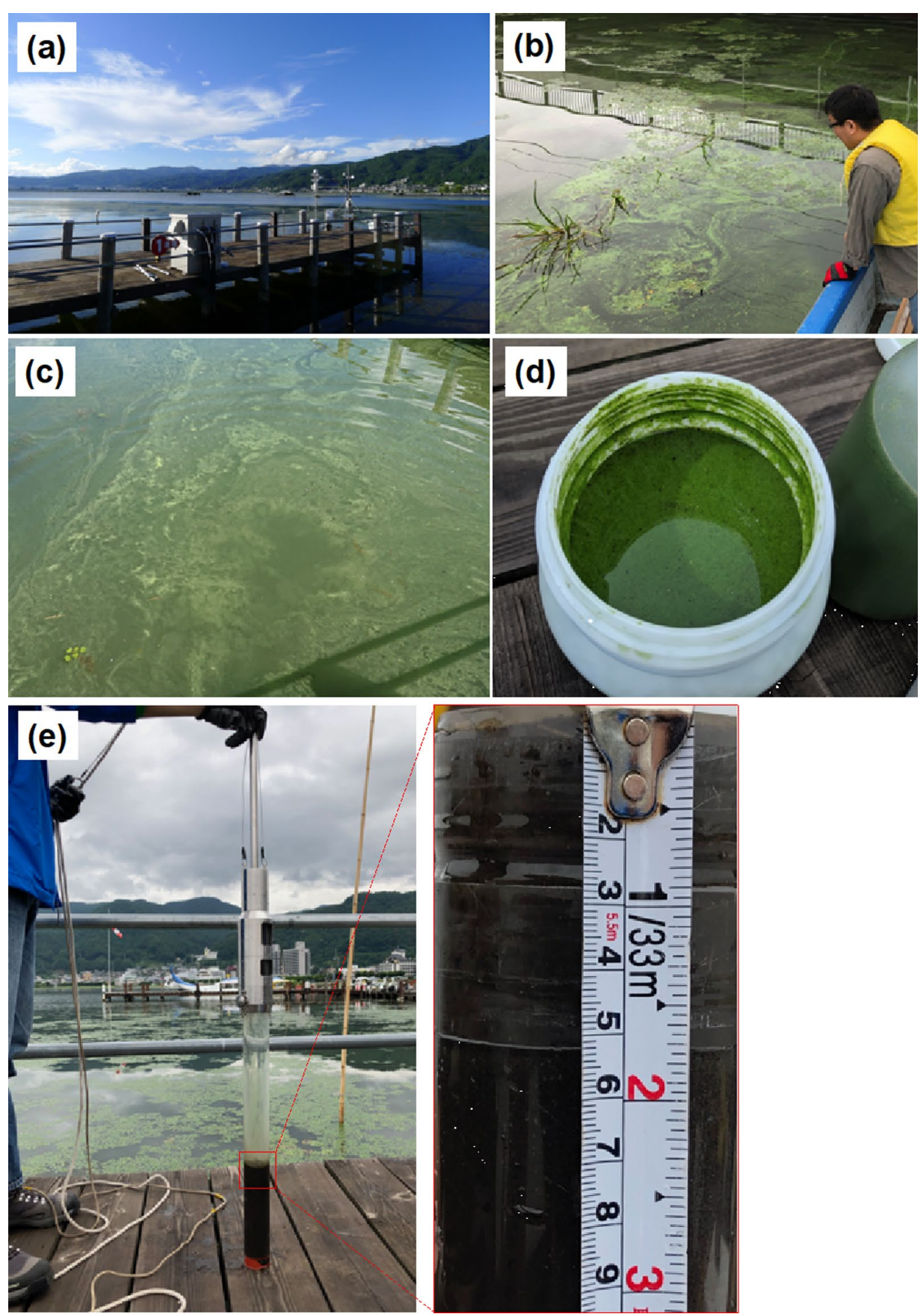

Fig. 2 Photographs of the sampling site and samples in June 2019. a Sampling site in the present study. The pier extends $40 \mathrm{~m}$ from the lakeshore and attains a depth of $1.8 \mathrm{~m}$. b, c Floating cyanobacteria near the sampling site. $\mathbf{d}$ Planktonic cyanobacterial sample collected in a polypropylene bottle. e Sediment core collection with a gravity core sampler 
measured with a Quant-i $\mathrm{T}^{\mathrm{TM}}$ dsDNA HS Assay Kit and a Qubit Fluorometer (Thermo Fisher Scientific, MA, USA). The SSU rRNA genes in the extracted DNA were amplified via polymerase chain reaction (PCR) using TaKaRa LA Taq (TaKaRa Bio, Shiga, Japan) according to the manufacturer's protocol. The 530F/907R primer set (V4-V5 regions) covering most bacterial and archaeal SSU rRNA genes (Nunoura et al. 2012) was used. This primer set can also detect some eukaryotic SSU rRNA gene sequences, but it does not cover all eukaryotes. Therefore, eukaryote-derived sequences were excluded, and archaea- and bacteria-derived sequences, approximately $380 \mathrm{bp}$ long of merged sequences that are the two-ended reads, were used to analyze the microbial community structure. The PCR amplification conditions were as described previously (Hirai et al. 2017). The amplified SSU rRNA gene sequences were analyzed using MiSeq (Illumina, CA, USA). Paired-end reads were merged using PEAR (Zhang et al. 2014). Low-quality (a Q score $<30$ in over $3 \%$ of all sequences), short reads $(<150 \mathrm{bp})$ and long reads ( $>500 \mathrm{bp}$ ) were filtered out with a customized Perl script. After chimeric sequences had been removed with Usearch61 (Edgar 2010) in QIIME (Caporaso et al. 2010), operational taxonomic units (OTUs) at a 97\% similarity level were selected using UCLUST (Edgar 2010) and assigned taxonomically (at the phylum, class, order, family, and genus levels) based on the SILVA 132 database (Quast et al. 2012).

\subsubsection{Nucleotide sequence accession numbers}

The SSU rRNA gene tag sequence data reported in this manuscript have been deposited in BioProject under accession number DRA009781.

\subsubsection{PCR amplification of the archaeal 16S rRNA and mcr A genes}

To confirm the presence of methanogenic archaea in the samples, the archaeal 16S rRNA and mcrA genes were amplified considering the extracted DNA by PCR with TaKaRa LA Taq (TaKaRa Bio) according to the manufacturer's protocol. The archaeal $16 \mathrm{~S}$ rRNA gene was amplified with the $340 \mathrm{~F} / 1000 \mathrm{R}$ primer set (Gantner et al. 2011), while the mcrA genes were amplified using the Luton-mcrA F/R, MCR F/MCR R, ME 3F/ME 2R, and mlas/mcrA-rev primer sets (Springer et al. 1995; Luton et al. 2002; Steinberg and Regan 2008; Sørensen et al. 2009). The PCR conditions involved denaturation at $95^{\circ} \mathrm{C}$ for $9 \mathrm{~min}$, followed by 45 cycles of denaturation at $94{ }^{\circ} \mathrm{C}$ for $40 \mathrm{~s}$, annealing at $50{ }^{\circ} \mathrm{C}, 52{ }^{\circ} \mathrm{C}$, or $55^{\circ} \mathrm{C}$ for $30 \mathrm{~s}$, extension at $72{ }^{\circ} \mathrm{C}$ for $40 \mathrm{~s}$, and a final extension step at $72{ }^{\circ} \mathrm{C}$ for $7 \mathrm{~min}$. The size of the PCR products was assessed via electrophoresis through a $1.5 \%$ agarose gel stained with RedSafe ${ }^{\mathrm{TM}}$ Nucleic Acid Stain Solution (FroggaBio, Toronto, Canada).

\subsubsection{A culture experiment using the cyanobacteria}

We performed a short-term culture experiment using the cyanobacterial bloom sample collected from Lake Suwa (date: 29-June-2019). The laboratory-based incubation was previously described in Han et al. (2012). Briefly, the cyanobacterial bloom sample was cultured in 10L plastic bottle with MA growth medium. The light/dark cycles was 12:12 (light: 9:00 to 21:00) and incubation temperature was $23{ }^{\circ} \mathrm{C} . \mathrm{CH}_{4}$ in the head space was analyzed by Ultraportable Greenhouse Gas Analyzer (Los Gatos Research, USA) under bright light conditions.

\subsubsection{Carbon and nitrogen measurement}

The total organic carbon (TOC) and total nitrogen (TN) contents and their stable isotopic ratios $\left({ }^{13} \mathrm{C} /{ }^{12} \mathrm{C}\right.$ and ${ }^{15} \mathrm{~N} /{ }^{14} \mathrm{~N}$, respectively) were measured in the planktonic cyanobacteria and core-top sediment collected in September 2018. All samples were freeze-dried, crushed, and homogenized prior to analysis. The benthic sediment was treated with $1 \mathrm{M} \mathrm{HCl}$ to remove carbonates and centrifuged $(\sim 2000 g)$ for $5 \mathrm{~min}$, and the precipitate was thoroughly washed with deionized water. This procedure was repeated three to five times before the sample was dried and pulverized. Measurements were conducted with an ultrasensitive elemental analyzer connected to an isotope ratio mass spectrometer (Flash EA1112 coupled to a Thermo Finnigan Delta plus XP via ConFlo III; Thermo Finnigan, CA, USA), as described previously (Ogawa et al. 2010). The isotopic composition was expressed in conventional $\delta$ notation:

$$
\delta=\left(\frac{\mathrm{R}_{\text {sample }}}{\mathrm{R}_{\text {standard }}}-1\right) \times 1000(\%),
$$

where $\mathrm{R}$ denotes the ${ }^{13} \mathrm{C} /{ }^{12} \mathrm{C}$ or ${ }^{15} \mathrm{~N} /{ }^{14} \mathrm{~N}$ ratio. The carbon and nitrogen isotope standards were Vienna Pee Dee Belemnite (VPDB) and atmospheric $\mathrm{N}_{2}$ (AIR), respectively. The carbon and nitrogen contents and their isotopic compositions were calibrated against three reference materials: L-tyrosine (BG-T: C, 59.7\%; $\mathrm{N}, \quad 7.74 \% ; \quad \delta^{13} \mathrm{C},-20.83 \pm 0.10 \% ; \quad \delta^{15} \mathrm{~N},+8.74 \pm 0.09$ $\%$ ), DL-alanine (CERKU-01: C, 40.4\%; N, 15.7\%; $\delta^{13} \mathrm{C},-25.36 \pm 0.08 \% ; \delta^{15} \mathrm{~N},-2.89 \pm 0.04 \%$ ), and glycine (CERKU-03: C, 32.0\%; N: 18.7\%; $\delta^{13} \mathrm{C},-34.92 \pm 0.07$ $\%$; $\delta^{15} \mathrm{~N},+2.18 \pm 0.04 \%$ ) (Tayasu et al. 2011). The analytical errors in the isotopic composition estimated via repeated BG-T analyses (5.8-22.7 $\mu \mathrm{g} \mathrm{C;} \mathrm{0.75-2.9} \mu \mathrm{g} \mathrm{N})$

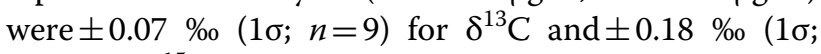
$n=9)$ for $\delta^{15} \mathrm{~N}$. 


\section{Results}

\subsection{Water column chemical profiles with the carbon and nitrogen contents}

Figure 3 a shows the water column profiles based on the measurements conducted in September 2018. Both the water temperature and the DO decreased with depth and ranged from 20.8 to $17.2{ }^{\circ} \mathrm{C}$ and 10.97 to $6.76 \mathrm{mg} \mathrm{L}^{-1}$, respectively. The DO saturation ranged from 134 to $77 \%$, suggesting that the water column was highly oxygenated from the surface to the bottom. The maximum $\mathrm{CH}_{4}$ concentration was observed between depths of 100 and $160 \mathrm{~cm}(3.5-3.6 \mu \mathrm{M})$ and decreased from 3.5 to $1.5 \mu \mathrm{M}$ in water shallower than $100 \mathrm{~cm}$. Similar trends were observed on the other measurement days (Fig. 3b).

We also analyzed the carbon and nitrogen contents and stable isotopic ratios of the samples collected in September 2018 (Table 1). Among the cyanobacterial samples, the TOC and TN contents were $41.1 \pm 1.8$ wt.\% and $7.7 \pm 1.08$ wt.\%, respectively, with $\delta^{13} \mathrm{C}$ and $\delta^{15} \mathrm{~N}$ values of $-26.5 \pm 0.3 \%$ o and $+8.8 \pm 0.5 \%$, respectively. Conversely, the sediment samples exhibited lower TOC and TN contents of $5.5 \pm 0.9$ wt.\% and $0.3 \pm 0.04$ wt.\%, respectively, with $\delta^{13} \mathrm{C}$ and $\delta^{15} \mathrm{~N}$ values of $-27.6 \pm 0.4 \%$ and $+3.0 \pm 0.9 \%$, respectively. The observed carbon and nitrogen isotopic compositions were typical of the lacustrine range in Lake Suwa (cf. Yoshioka et al. 1988, 1994), and the cyanobacterial and sediment samples exhibited TOC/TN ratios of $5.4 \pm 0.6$ and $17.2 \pm 0.6$, respectively. The carbon and nitrogen isotope ratios presented in this study are in the typical cyanobacterial profiles (i.e., native feature of phototrophic $\mathrm{N}_{2}$-fixation) and are consistent with the findings presented in previous reports (Yoshioka et al. 1988; Ohkouchi and Takano 2014).

\subsection{Concentration of F430}

We detected F430 in the planktonic and benthic samples by using LC/ESI-MS/MS in MRM mode (Fig. 4). The planktonic samples collected in September 2018 and June 2019 exhibited F430 concentrations of $6.8 \times 10^{2}$ and $3.5 \times 10^{3}$ femto mol g-wet ${ }^{-1}$, respectively (Table 2 ), or $9.2 \times 10^{3}$ and $5.6 \times 10^{4}$ femto mol g-dry ${ }^{-1}$, respectively, considering the water content in the cyanobacteria, i.e., the water contents in both cyanobacterial samples were 92.5 and $93.8 \%$, respectively. Conversely, the F430 concentrations in the core-top sediment obtained in September 2018 and June 2019 were $8.5 \times 10^{2}$ and $8.6 \times 10^{3}$ femto mol g-wet ${ }^{-1}$, respectively. The peak ratios of native F430 to its epimers were 3.3 and 3.8 in the cyanobacteria and 9.0 and 11.1 in the benthic sediment, respectively (Table 2). The small amounts of F430M epimers detected in the samples collected in this study (Fig. 4b, c) indicated that most methanogenic archaea were activated.

\subsection{Microbial community structure in the planktonic and surface sediment samples}

First, Fig. 5 shows a photomicrograph of the planktonic cyanobacteria collected in June 2019, in which large numbers of cells were confluent and formed colonies with a morphology similar to that of cyanobacteria of the genus Microcystis (Xu et al. 2016). The detailed microbial communities in the cyanobacteria and core-top sediment collected in September 2018 were investigated via SSU rRNA gene tag sequencing analysis. A total of 65,884 reads were obtained from the planktonic cyanobacteria, of which $99.5 \%$ were assigned to bacteria (Fig. 6a, b). More than $50 \%$ of the bacterial reads were assigned to a single OTU and were closely related to the cyanobacterium genus Microcystis in the order Nostocales (Fig. 6c). We detected another cyanobacterium genus, Pseudanabaena, in the order Pseudanabaenales. In addition to cyanobacteria, bacteria closely related to the orders Acetobacterales (mainly Acetobacteraceae), Betaproteobacteriales (mainly uncultured Nitrosomonadaceae, Azohydromonas, Ramlibacter, and Noviherbaspirillum), Caulobacterales (mainly uncultured Caulobacteraceae), and Cytophagales (mainly uncultured Microscillaceae) were detected, which are generally regarded as aerobic heterotrophic or aerobic ammonia-oxidizing bacteria. A small proportion ( $0.3 \%)$ of the total sequence reads was assigned to eukaryotic $18 \mathrm{~S}$ rRNA genes, mainly stemming from Cnidaria, Conthreep, Bilateria, and Heterotrichea.

Second, a total of 46,182 reads were obtained from the benthic sediment, of which 92.8 and $6.9 \%$ were assigned to bacteria and archaea, respectively (Fig. 6d). Methanogenic archaea belonging to the classes Methanobacteria (Methanobacterium) and Methanomicrobia (largely Methanoregula, Methanothrix, Methanosarcina, and Methanocella) were confirmed in the archaeal community (Fig. 6e). The majority of the archaeal reads were assigned to the candidate phyla Bathyarchaeota and Woesearchaeota and the class Thermoplasmata (largely Marine Benthic Group-D). Although these predominant archaeal groups are also frequently encountered in marine and freshwater ecosystems, groundwater, and thermal springs, little is known about their physiology or metabolism due to the lack of cultured representatives (e.g., Evans et al. 2015; Tarnovetskii et al. 2018; Zhou et al. 2018, 2019). Compared to the planktonic cyanobacteria, the bacterial community in the sediment samples was extremely diverse (Fig. 6f), with relatively abundant bacterial reads closely related to the orders Betaproteobacteriales (mostly Sulfuritalea, Quatrionicoccus, uncultured Nitrosomonadaceae, and uncultured Burkholderiaceae), Gaiellales (mostly uncultured), Anaerolineales (mostly uncultured Anaerolineaceae), and Clostridiales (mostly 


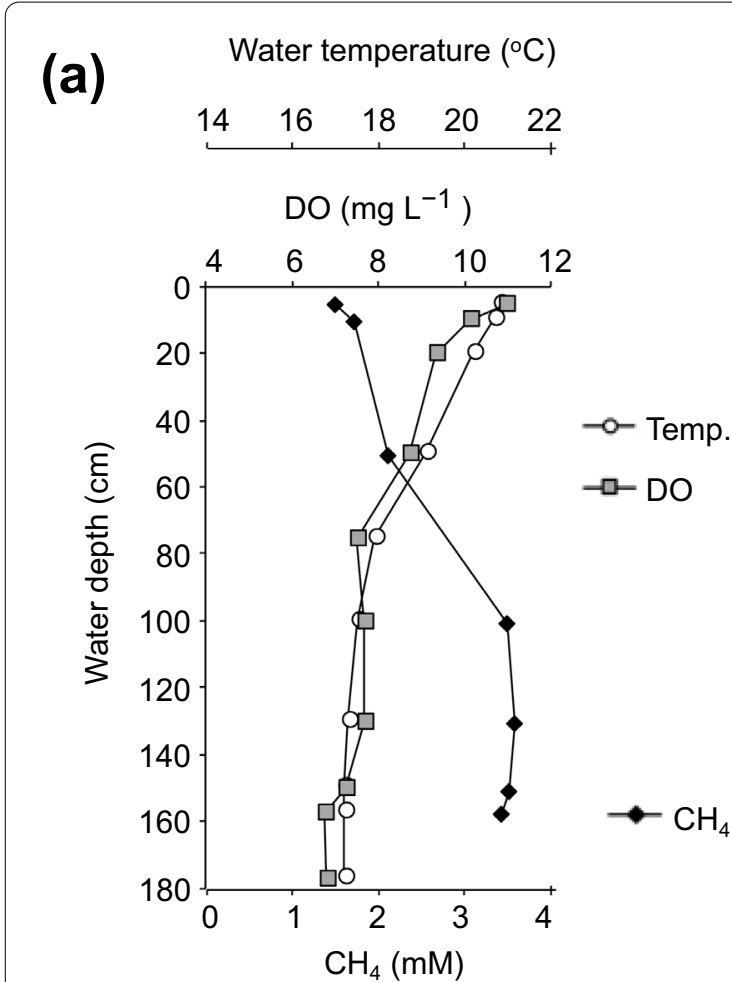

(b) Principal component loading in June (PC1)

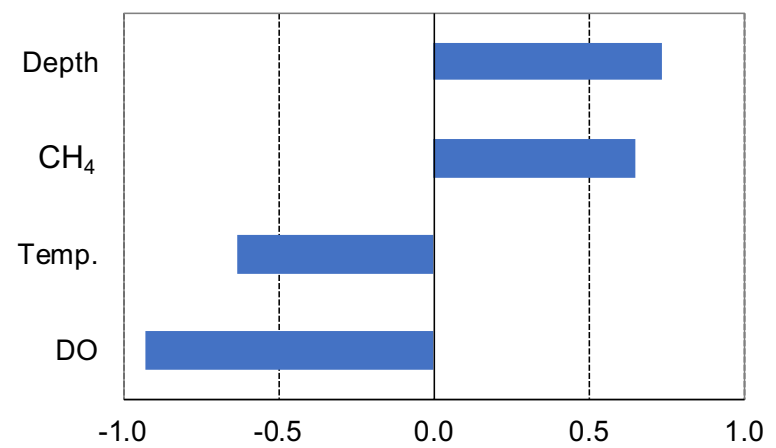

Principal component loading in Sept. \& Oct. (PC1)

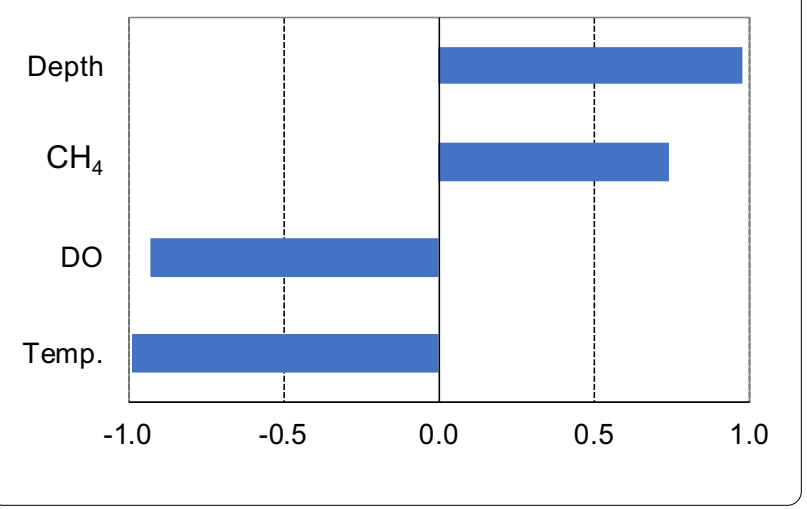

Fig. 3 a Cross-section of Lake Suwa and water column profiles measured in September 2018. Here, we note that planktonic cyanobacteria move toward a lower water layer at night and rise to the surface layer before dawn (Reynolds 1987). b Principal component loading for the water depth $(\mathrm{cm})$, water temperature $\left({ }^{\circ} \mathrm{C}\right)$, dissolved oxygen $(\mathrm{mg} / \mathrm{L}), \mathrm{CH}_{4}(\mathrm{mmol} / \mathrm{L})$ in the sampling site at Lake Suwa for early summer season (June in 2018 and 2019, $n=12$ ) and autumn season (September to October in 2018 and 2019, $n=13$ )

Romboutsia, Clostridium, and Sarcina). These bacteria include aerobic heterotrophic (Burkholderiaceae), anaerobic autotrophic (Sulfuritalea), anaerobic heterotrophic (Anaerolineales, Clostridiales), and ammonia-oxidizing (Nitrosomonadaceae) species, which have often been reported in the sediments of freshwater lakes (Buckles et al. 2013; Watanabe et al. 2017; Chen et al. 2017).

\subsection{Genomic indicators of the methanogenic archaea}

To detect methanogenic archaea in both the planktonic and the benthic samples, we amplified the archaeal $16 \mathrm{~S}$ rRNA and $m c r A$ genes in the total extracted DNA using PCR with the above one and four primer sets, respectively. The archaeal 16S rRNA and mcrA genes were successfully amplified from the benthic sediment (Table 3), while the PCR amplicons from the cyanobacteria were not significant after repeated attempts. A wet-chemical improvement to eliminate the sample matrix effect (e.g., extracellular polysaccharides stemming from cyanobacteria) is required for further confirmation of the current preliminary results.

\subsection{The head-space methane during the culture experiment}

Figure 7 showed the concentration $\mathrm{CH}_{4}$ profile in the head-space with the incubation time. The $\mathrm{CH}_{4}$ concentration was normalized by the difference of initial concentration $(t=0$, hour) to each corresponding time $(<t=9)$. We confirmed a rapid increase in methane concentration within the incubation time. Therefore, the preliminary results indicated that the cyanobacterial bloom sample produced $\mathrm{CH}_{4}$ under aerobic condition (cf. Bižić et al. 2020), and its production rate was determined about $1.39 \mathrm{nM} \mathrm{h}^{-1}$. The data presented in this preliminary culture experiment supports the evidence for in-situ methane production (Fig. 7). In our future survey, it is necessary to conduct culture studies with different conditions (i.e., light and dark conditions, water temperature, medium) with a microbial ecological link to methane producing archaea. 
Table 1 Carbon and nitrogen contents and their stable isotopic compositions in the planktonic and benthic samples

\begin{tabular}{|c|c|c|c|c|c|}
\hline Sample & $\begin{array}{l}\text { TOC } \\
\text { (wt\%) }\end{array}$ & $\begin{array}{l}\text { TN } \\
\text { (wt\%) }\end{array}$ & $\begin{array}{l}\delta^{13} \mathrm{C} \\
\text { (\%o, vs VPDB) }\end{array}$ & $\begin{array}{l}\delta^{15} \mathrm{~N} \\
(\% \text {, vs AIR) }\end{array}$ & $\begin{array}{l}\text { TOC/TN } \\
\text { (wt\%/wt\%) }\end{array}$ \\
\hline $\begin{array}{l}\text { Planktonic cyanobacteria } \\
\text { (September 2018) }\end{array}$ & $41.1 \pm 1.8$ & $7.7 \pm 1.1$ & $-26.5 \pm 0.3$ & $+8.8 \pm 0.5$ & $5.4 \pm 0.6$ \\
\hline $\begin{array}{l}\text { Sediment 0-10 cm depth } \\
\text { (September 2018) }\end{array}$ & $5.5 \pm 0.9$ & $0.3 \pm 0.0$ & $-27.6 \pm 0.4$ & $+3.0 \pm 0.9$ & $17.2 \pm 0.6$ \\
\hline
\end{tabular}

\section{(a)}

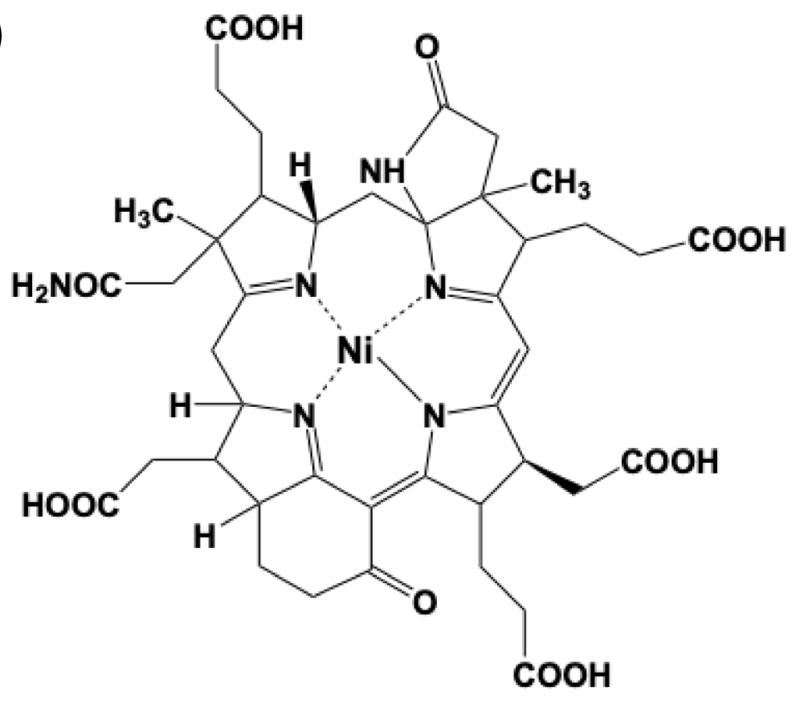

(b)
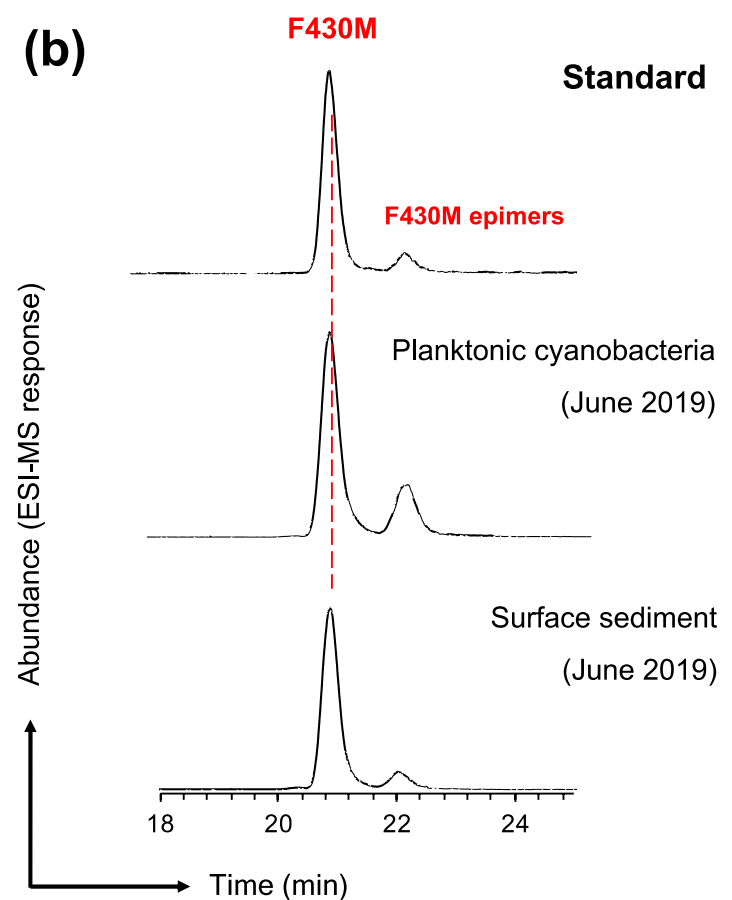

(c)

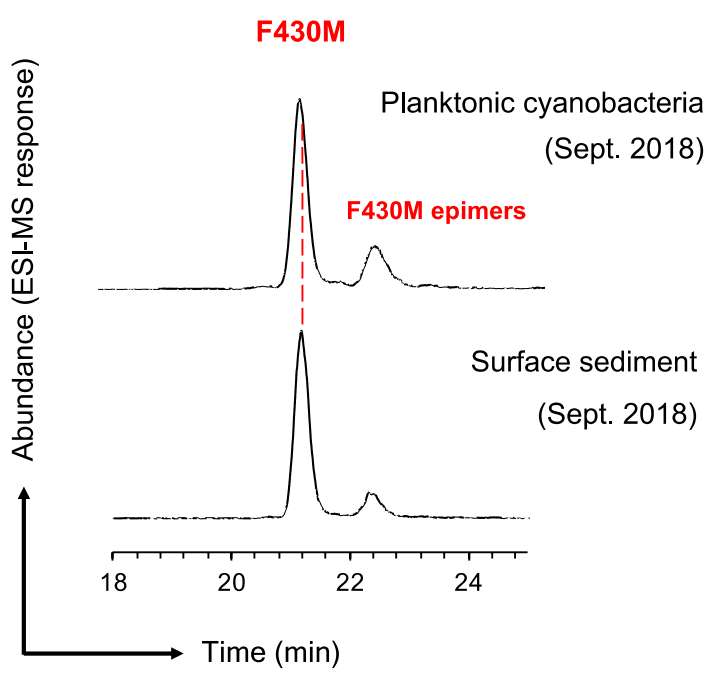

Fig. 4 a Structure of coenzyme factor 430 (F430), which has a chemical formula of $\mathrm{C}_{42} \mathrm{H}_{51} \mathrm{~N}_{6} \mathrm{NiO}_{13}$. $\mathrm{F} 430$ is a hydrocorphinoid nickel complex that functions as an active site in MCR. The MCR-F430 complex catalyzes the last step of methanogenesis involving the reduction of methyl coenzyme M into $\mathrm{CH}_{4}$. b, c Chromatograms of the planktonic cyanobacterial samples analyzed via LC/ESI-MS/MS in MRM mode (Kaneko et al. 2014). The F430M product ion was set to $\mathrm{m} / \mathrm{z}$ 844.3. The concentration of native F430 with assessment of the F430 epimer ratio enabled us to estimate the biomass of the in situ living methanogenic archaea (Kaneko et al. 2021) 
Table 2 Concentrations of coenzyme F430 and its epimer ratios in the planktonic and sediment samples collected from Lake Suwa

\begin{tabular}{|c|c|c|c|c|c|}
\hline \multirow{2}{*}{$\begin{array}{l}\text { Sample type } \\
\text { Planktonic microbes }\end{array}$} & \multirow{2}{*}{$\begin{array}{l}\text { Sample name } \\
\text { Cyanobacteria } \\
\text { (September 2018) }\end{array}$} & \multicolumn{2}{|c|}{ Concentration } & \multirow{2}{*}{$\begin{array}{l}\text { F430/F430 } \\
\text { epimer }\end{array}$} & \multirow{2}{*}{$\begin{array}{l}\text { References } \\
\text { This study }\end{array}$} \\
\hline & & $6.8 \times 10^{2}$ & femto mol g-wet ${ }^{-1}$ & & \\
\hline & $\begin{array}{l}\text { Cyanobacteria } \\
\text { (June 2019) }\end{array}$ & $3.5 \times 10^{3}$ & femto mol g-wet ${ }^{-1}$ & 3.8 & This study \\
\hline \multirow[t]{4}{*}{ Sediment } & $\begin{array}{l}\text { Sediment 0-10 cm depth } \\
\text { (September 2018) }\end{array}$ & $8.5 \times 10^{2}$ & femto $\mathrm{mol} \mathrm{g- \text {wet } ^ { - 1 }}$ & 9.0 & This study \\
\hline & $\begin{array}{l}\text { Sediment 0-3 cm depth } \\
\text { (June 2019) }\end{array}$ & $8.6 \times 10^{3}$ & femto mol g-wet ${ }^{-1}$ & 11.1 & This study \\
\hline & $\begin{array}{l}\text { Kawatabi } \\
\text { (Paddy soil) }\end{array}$ & $8.7 \times 10^{2}$ & 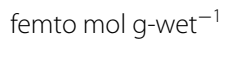 & - & Kaneko et al. (2014) \\
\hline & $\begin{array}{l}\text { Shimokita 11-4 } \\
\text { (Marine sediment) }\end{array}$ & $6.3 \times 10^{1}$ & femto mol g-wet ${ }^{-1}$ & - & Kaneko et al. (2014) \\
\hline
\end{tabular}

(a)

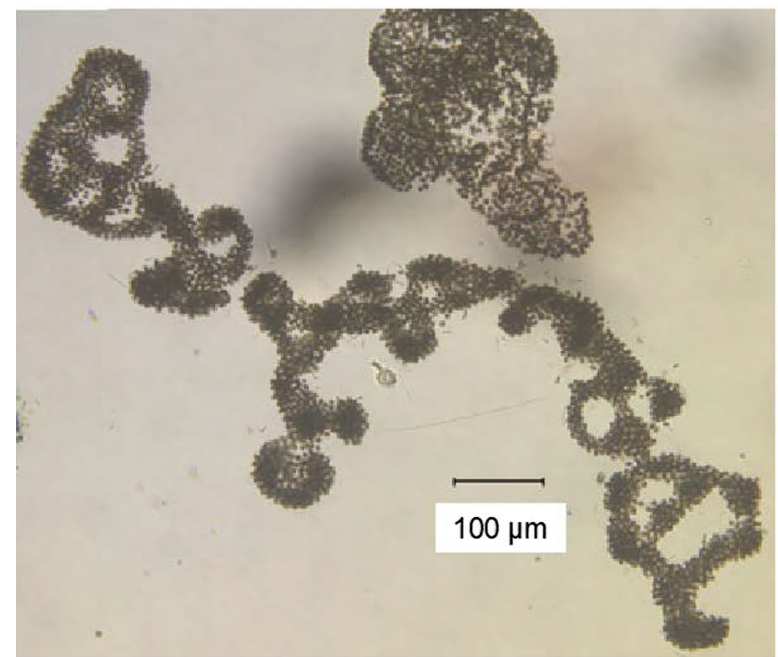

(b)

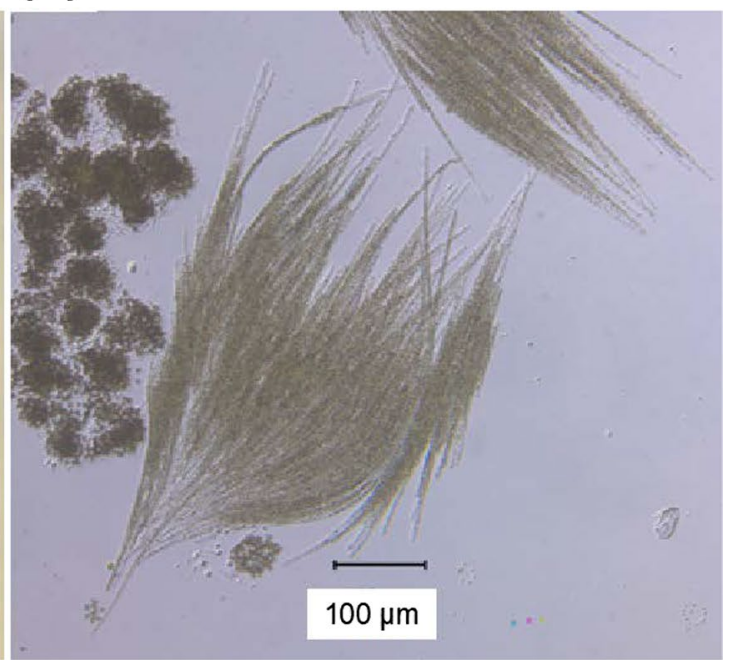

Fig. 5 Photomicrograph of the planktonic cyanobacterial sample collected in June 2019. The cyanobacteria in Lake Suwa mainly include Microcystis (a) in addition to other cyanobacteria, such as Aphanizomenon (b). We note previous studies regarding the average cellular dry weight and average cellular volume of Microcystis aeruginosa $\left(2.0 \times 10^{-11} \mathrm{~g}\right.$ cell ${ }^{-1}$, Li et al. 2014; $65 \mathrm{\mu m}^{3} \mathrm{cell}^{-1}$, Olenina et al. 2006)

\section{Discussion}

\subsection{Planktonic and benthic concentrations of F430 for potential methane production}

F430 is unstable and rapidly epimerizes to its relic forms (13-epi-F430 and 12,13-diepi-F430) via a process occurring on a daily basis, even at room temperature (Diekert et al. 1981; Mayr et al. 2008; Inagaki et al. 2015); therefore, the native form of F430 is unlikely to accumulate in the environment after the death of methanogenic archaeal cells. The concentration of native F430 with assessment of the F430 epimer ratio enabled us to estimate the biomass of the in situ living methanogenic archaea (Kaneko et al. 2014, 2021). In this study, we detected native F430 in the planktonic cyanobacterial sample (i.e., $6.8 \times 10^{2}$ to $3.5 \times 10^{3}$ femto mol g-wet ${ }^{-1}$ ), indicating the presence of methanogenic archaea in the water column environment (Fig. 4, Table 2). Although active photosynthesis simultaneously generates oxygen, certain methanogenic archaea are considered to tolerate oxygen exposure for long periods (Angel et al. 2011). Assemblages of heterotrophic bacteria are contained within the cyanobacterial phycosphere, and their respiration 


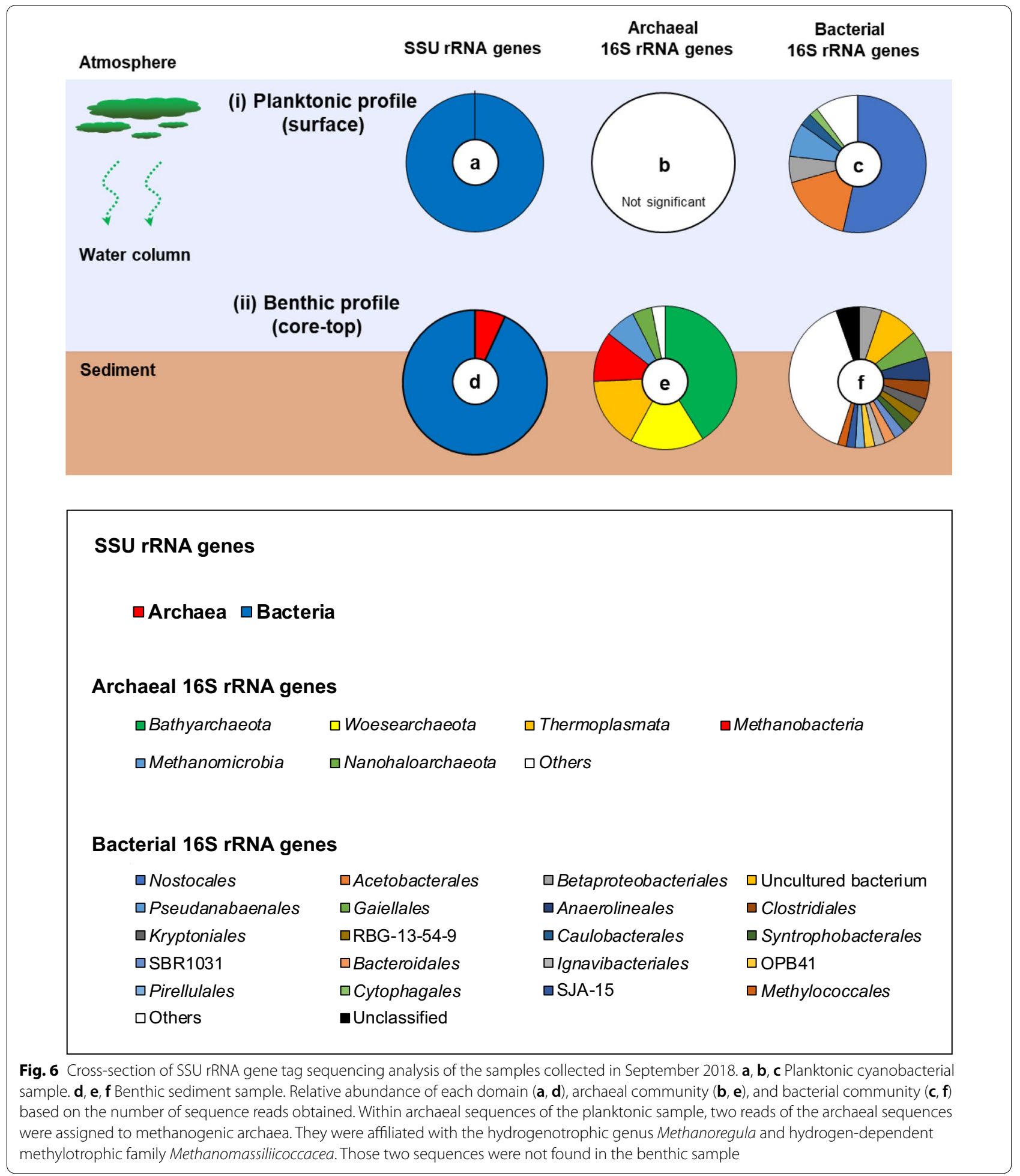

leads to an oxygen gradient (e.g., Ploug 2008; Dziallas and Grossart 2012; Batista et al. 2019). Very small amounts of F430 epimers were also detected from the planktonic cyanobacterial samples based on the ratio of native F430 to the epimer in these samples ranging from 3.3 to 3.8 (Table 2), suggesting that native F430 occurs in an active 
Table 3 PCR amplification of the archaeal 16S rRNA and mcrA genes. The PCR products were loaded onto a 1.2\% agarose gel with negative and positive controls and a DNA size standard

\begin{tabular}{|c|c|c|c|c|c|}
\hline \multirow{2}{*}{$\begin{array}{l}\text { Target } \\
\text { PCR primer set }\end{array}$} & \multirow{2}{*}{$\begin{array}{l}\text { Archaeal 16S rRNA gene } \\
340 \mathrm{~F} / 1000 \mathrm{R}\end{array}$} & \multicolumn{4}{|l|}{$m c r A$ gene } \\
\hline & & $\begin{array}{l}\text { Luton-mcrA } \\
\text { F/R }\end{array}$ & MCR F/MCR R & ME 3F/ME 2R & mlas/mcrA-rev \\
\hline $\begin{array}{l}\text { Planktonic cyanobacteria } \\
\text { (September 2018) }\end{array}$ & - & - & - & - & - \\
\hline $\begin{array}{l}\text { Sediment 0-10 cm depth } \\
\text { (September 2018) }\end{array}$ & + & + & - & + & + \\
\hline
\end{tabular}

The presence or absence of the PCR product is indicated as $(+)$ and $(-)$, respectively. The annealing temperature for each primer set is listed in Table 4

Table 4 PCR primers for archaeal 16S rRNA and mcrA genes for the present initial report

\begin{tabular}{|c|c|c|c|c|c|}
\hline Target & Primer name & Direction & Sequences $\left(5^{\prime} \rightarrow 3^{\prime}\right)$ & $\begin{array}{l}\text { Hybridization } \\
\text { temperature }\left({ }^{\circ} \mathrm{C}\right)\end{array}$ & References \\
\hline \multirow{2}{*}{$\begin{array}{l}\text { Archaeal } 16 \mathrm{~S} \\
\text { rRNA gene }\end{array}$} & $340 \mathrm{~F}$ & Forward & CCCTAYGGGGYGCASCAG & \multirow[t]{2}{*}{52} & \multirow[t]{2}{*}{ Gantner et al. (2011) } \\
\hline & $1000 R$ & Reverse & GGCCATGCACYWCYTCTC & & \\
\hline \multirow[t]{2}{*}{ mcrA gene } & Luton-mcrA F & Forward & GGTGGTGTMGGATTCACACARTAYGCWACAGC & \multirow[t]{2}{*}{50} & \multirow[t]{2}{*}{ Luton et al. (2002) } \\
\hline & Luton-mcrA R & Reverse & TTCATTGCRTAGTTWGGRTAGTT & & \\
\hline \multirow[t]{2}{*}{ mcrA gene } & MCRF & Forward & TAYGAYCARATHTGGYT & \multirow[t]{2}{*}{50} & \multirow[t]{2}{*}{ Springer et al. (1995) } \\
\hline & MCRR & Reverse & ACRITCATNGCRTARTT & & \\
\hline \multirow[t]{2}{*}{ mcrA gene } & ME 3F & Forward & ATGTCNGGTGGHGTMGGSTTYAC & \multirow[t]{2}{*}{55} & \multirow[t]{2}{*}{ Sørensen et al. (2009) } \\
\hline & ME $2 R$ & Reverse & TCATBGCRTAGTTDGGRTAGT & & \\
\hline \multirow[t]{2}{*}{ mcrA gene } & mlas & Forward & GGTGGTGTMGGDTTCACMCARTA & \multirow[t]{2}{*}{55} & \multirow[t]{2}{*}{ Steinberg and Regan (2008) } \\
\hline & mcrA-rev & Reverse & CGTTCATBGCGTAGTTVGGRTAGT & & \\
\hline
\end{tabular}

state in the water column (cf. Urai et al. 2021). Therefore, the planktonic methanogen coexisting in the water column may produce $\mathrm{CH}_{4}$ when oxygen production via photosynthesis ceases at night, as proposed by Bižic et al. (2020). We determined the gene extraction method for cyanobacterial bloom after comparing several extraction kits. Previous study reported that cyanobacterial cells are rich in polysaccharides, which make it difficult to obtain highly purified nucleic acid (e.g., Yoshida et al. 2003). However, we detected archaeal gene reads in cyanobacterial bloom, indicating that the method can detect archaeal gene from cyanobacteria. To evaluate the actual $\mathrm{CH}_{4}$ production rate in the water column of Lake Suwa, preliminary short-term incubation experiments were performed by using the same planktonic cyanobacterial samples (Fig. 7).

SSU rRNA gene tag sequencing analysis detected a large number of $16 \mathrm{~S}$ rRNA genes originating from aerobic heterotrophic bacteria, including Acetobacterales and Betaproteobacteriales, in the cyanobacterial sample (Fig. 6). Some Acetobacterales species produce acetate as a metabolite ( $\mathrm{Vu}$ et al. 2019); therefore, these heterotrophic bacteria may supply methanogenic archaea with methanogenic substrates via decomposition of the organic matter produced during cyanobacterial photosynthesis. Berg et al. (2014) proposed that hydrogenotrophic methanogenic archaea utilize the hydrogen generated by cyanobacteria during nitrogen fixation; however, since Microcystis, which was dominant in our samples (Fig. 6c), lacks nitrogenase required for nitrogen fixation (Kim et al. 2019), its contribution to $\mathrm{CH}_{4}$ production appears to be quite small in surface water. Although we detected F430 in the planktonic cyanobacterial samples (Fig. 4), the samples contained extremely small numbers of SSU rRNA gene sequences from known methanogenic archaea, and no PCR amplicons from archaeal $16 \mathrm{~S}$ rRNA and $m c r A$ genes were obtained (Fig. 4, Table 3). Previous studies have estimated the in situ cellular abundance of methanogenic archaea based on the F430 concentration (Takano et al. 2013; Kaneko et al. 2014); however, a technical discrepancy between the F430 concentration and molecular analyses has been reported (e.g., Inagaki et al. 2015; Kaneko et al. 2016; Urai et al. 2021). Although an equation has been proposed to convert the F430 concentration into the number of methanogenic archaea, deep insights are currently lacking to widely apply the equation. Therefore, method development is required in this preliminary study to refine the 


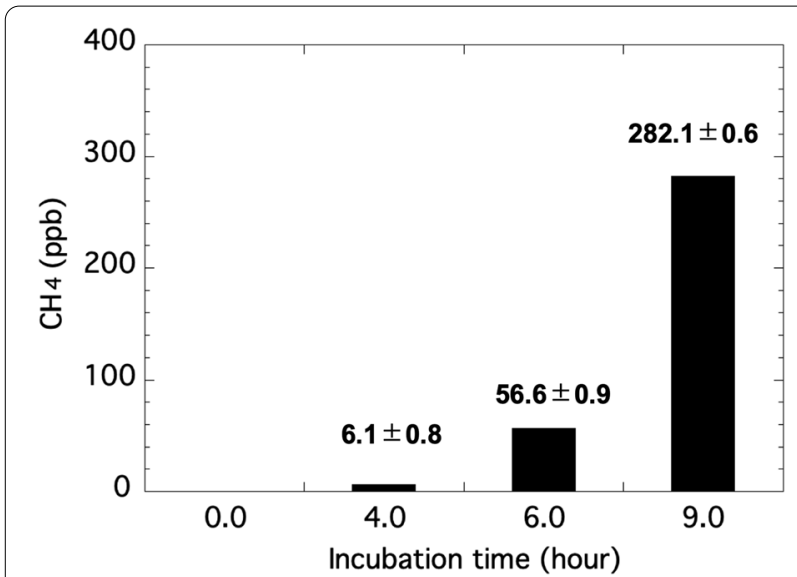

Fig. 7 The time profiles of $\mathrm{CH}_{4}$ concentration in head space by a short-term culture experiment. The data showed the average value of the measurement of $\mathrm{CH}_{4}$ in the gas phase within the incubation time ( $t=0,4,6,9 h ; t=0$ as initial concentration)

comparison to rRNA gene sequencing and quantitative examinations.

Regarding the benthic methane production process, we quantified F430 in the benthic sediment samples collected in September $2018\left(8.5 \times 10^{2}\right.$ femto mol g-wet $\left.{ }^{-1}\right)$ and June $2019\left(8.6 \times 10^{3}\right.$ femto mol g-wet $\left.{ }^{-1}\right)$, revealing levels similar to or higher than those previously reported in marine sediment $\left(0.026-1.9 \times 10^{3}\right.$ femto mol g-wet $\left.{ }^{-1}\right)$ and paddy soil $\left(0.3-2.0 \times 10^{3}\right.$ femto mol g-wet $^{-1}$ ) (Kaneko et al. 2014, 2016), suggesting ongoing archaeal methanogenesis in the benthic sediment. The $\mathrm{CH}_{4}$ production rate in the benthic sediment $(5-30 \mathrm{~cm}$ depth) of Lake Suwa has been reported to range from

Table 5 Correlation matrix of the water depth $(\mathrm{cm})$, water temperature $\left({ }^{\circ} \mathrm{C}\right)$, dissolved oxygen $(\mathrm{mg} / \mathrm{L})$, and $\mathrm{CH}_{4}(\mathrm{mmol} / \mathrm{L})$ in the sampling site at Lake Suwa; (a) early summer season (June in $2018 \& 2019, n=12$ ) and (b) autumn season (September to October in 2018 and $2019, n=13$ )

\begin{tabular}{lclll}
\hline & Depth & Temp. & DO & $\mathbf{C H}_{\mathbf{4}}$ \\
\hline (a) June in 2018 and 2019 & $(n=12)$ & & \\
Depth & 1 & -0.042 & -0.475 & 0.657 \\
Temp & -0.042 & 1 & 0.844 & 0.059 \\
DO & -0.475 & 0.844 & 1 & -0.379 \\
$\mathrm{CH}_{4}$ & 0.657 & 0.059 & -0.379 & 1 \\
(b) September to October in 2018 and 2019 $(n=13)$ & \\
Depth & 1 & -0.954 & -0.920 & 0.665 \\
Temp & -0.954 & 1 & 0.945 & -0.673 \\
DO & -0.920 & 0.945 & 1 & -0.450 \\
$\mathrm{CH}_{4}$ & 0.665 & -0.673 & -0.450 & 1 \\
\hline
\end{tabular}

Principal component statistics and raw data profiles are shown in the Fig. $3 \mathrm{~b}$ and Table 6, respectively
Table 6 Water column profiles at the sampling site between June 2018 and October 2019

\begin{tabular}{|c|c|c|c|c|}
\hline Date & $\begin{array}{l}\text { Depth } \\
\mathrm{cm}\end{array}$ & $\begin{array}{l}\text { Temp } \\
{ }^{\circ} \mathrm{C}\end{array}$ & $\begin{array}{l}\mathrm{DO} \\
\mathrm{mg} / \mathrm{L}\end{array}$ & $\begin{array}{l}\mathrm{CH}_{4} \\
\mathrm{mmol} / \mathrm{L}\end{array}$ \\
\hline \multirow[t]{11}{*}{ 2018.6.27 } & 0 & - & - & 1.80 \\
\hline & 5 & 24.5 & 8.61 & - \\
\hline & 10 & 24.5 & 8.61 & 2.09 \\
\hline & 20 & 24.5 & 8.61 & - \\
\hline & 50 & 24.5 & 8.66 & 2.05 \\
\hline & 75 & 24.5 & 8.58 & - \\
\hline & 100 & 24.5 & 8.64 & 2.26 \\
\hline & 130 & 24.5 & 8.43 & 1.83 \\
\hline & 150 & 24.5 & 7.83 & 2.05 \\
\hline & 160 & 24.5 & 7.16 & 2.36 \\
\hline & 180 & 24.5 & 6.48 & - \\
\hline \multirow[t]{11}{*}{ 2018.9.28 } & 0 & - & - & - \\
\hline & 5 & 20.8 & 10.97 & 1.52 \\
\hline & 10 & 20.7 & 10.11 & 1.73 \\
\hline & 20 & 20.2 & 9.34 & - \\
\hline & 50 & 19.1 & 8.74 & 2.13 \\
\hline & 75 & 17.9 & 7.50 & - \\
\hline & 100 & 17.5 & 7.68 & 3.50 \\
\hline & 130 & 17.3 & 7.67 & 3.60 \\
\hline & 150 & 17.2 & 7.24 & 3.53 \\
\hline & 160 & 17.2 & 6.76 & 3.45 \\
\hline & 180 & 17.2 & 6.80 & - \\
\hline \multirow[t]{11}{*}{ 2019.6.28 } & 0 & - & - & 0.92 \\
\hline & 5 & 22.9 & 7.16 & - \\
\hline & 10 & 22.9 & 7.13 & 1.07 \\
\hline & 20 & 23.0 & 7.12 & - \\
\hline & 50 & 23.0 & 7.11 & 1.17 \\
\hline & 75 & 23.0 & 6.94 & - \\
\hline & 100 & 23.0 & 6.85 & 1.43 \\
\hline & 130 & 22.9 & 6.31 & 2.25 \\
\hline & 150 & 22.8 & 5.75 & 2.76 \\
\hline & 160 & 22.7 & 4.92 & 3.03 \\
\hline & 180 & 22.7 & 4.84 & - \\
\hline \multirow[t]{11}{*}{ 2019.8.29 } & 0 & - & - & 2.78 \\
\hline & 5 & 25.7 & 7.49 & - \\
\hline & 10 & 25.6 & 7.51 & 0.61 \\
\hline & 20 & 25.5 & 7.54 & - \\
\hline & 50 & 25.4 & 7.40 & 0.37 \\
\hline & 75 & 24.4 & 3.22 & - \\
\hline & 100 & 23.9 & 1.32 & 0.23 \\
\hline & 130 & 23.4 & 2.77 & 0.94 \\
\hline & 150 & 22.6 & 1.86 & 3.38 \\
\hline & 160 & 22.4 & 1.22 & 13.59 \\
\hline & 180 & 22.3 & 0.83 & - \\
\hline
\end{tabular}


Table 6 (continued)

\begin{tabular}{lllll}
\hline Date & $\begin{array}{l}\text { Depth } \\
\mathbf{c m}\end{array}$ & $\begin{array}{l}\text { Temp } \\
{ }^{\circ} \mathbf{C}\end{array}$ & $\begin{array}{l}\text { DO } \\
\mathbf{m g} / \mathbf{L}\end{array}$ & $\begin{array}{l}\mathrm{CH}_{\mathbf{4}} \\
\mathbf{m m o l} / \mathbf{L}\end{array}$ \\
\hline 2019.10 .10 & 0 & - & - & 0.32 \\
5 & 20.9 & 10.06 & - \\
10 & 20.9 & 10.06 & 0.29 \\
20 & 20.9 & 10.08 & - \\
50 & 20.8 & 10.06 & 0.99 \\
75 & 18.9 & 8.98 & - \\
100 & 17.8 & 7.01 & 0.90 \\
130 & 16.9 & 5.50 & 1.83 \\
150 & 16.9 & 5.45 & 2.36 \\
160 & 16.8 & 5.23 & 2.37 \\
180 & 16.8 & 5.07 & - \\
& 160 & &
\end{tabular}

7.8-19.8 nmol g-dry ${ }^{-1} \mathrm{~h}^{-1}$ at the typical summer maximum surface sediment temperature (Iwata et al. 2020). Since Lake Suwa is a eutrophic lake, its benthic sediment contains high concentrations of organic carbon (Table 1); therefore, this nutrient-rich substrate could support benthic $\mathrm{CH}_{4}$ production (e.g., Zepp Fal et al. 1999). The correlation matrix of the water depth $(\mathrm{cm})$, water temperature $\left({ }^{\circ} \mathrm{C}\right), \mathrm{DO}(\mathrm{mg} / \mathrm{L})$, and $\mathrm{CH}_{4}(\mathrm{mmol} / \mathrm{L})$ in the early summer $(n=12)$ and autumn $(n=13)$ seasons during 2018-2019 is shown in Table 5.

\subsection{Drastic change between the planktonic and benthic microbial communities}

Archaeal 16S rRNA and $m c r A$ gene analysis detected the presence of methanogenic archaea closely related to Methanobacteriales and Methanomicrobiales in the benthic sediment (Fig. 6, Table 3), including hydrogenotrophic, aceticlastic, and methylotrophic methanogenic archaea (Sakai et al. 2012; Schirmack et al. 2014). The 16S rRNA genes of anaerobic heterotrophic bacteria were also detected in the benthic sediment (Fig. 6). Members of Anaerolineales and Clostridiales anaerobically decompose organic matter via fermentation and supply methanogenic archaea with their metabolites, such as $\mathrm{H}_{2}$, acetate, formate, and methanol (Yamada et al. 2006; Nishiyama et al. 2009). Although the bottom lake water contained DO (Fig. 3a), this DO may be rapidly consumed by aerobic heterotrophic bacteria in the benthic sediment, suggesting that $\mathrm{CH}_{4}$ is produced in the benthic sediment via the anaerobic decomposition of organic matter by fermentative bacteria and methanogenic archaea. The benthic sediment was dominated by the $16 \mathrm{~S}$ rRNA genes of archaea closely related to Bathyarchaeota, whose genomes reportedly contain divergent homologs of the genes required for methane metabolism (Evans et al. 2015). Thus, uncultured archaea belonging to Bathyarchaeota may also be involved in $\mathrm{CH}_{4}$ production in the surface sediment.

The microbial community structure differed between the water column and benthic sediment. The planktonic observations are consistent with a previous study (Microcystis spp., Park et al. 1993). In contrast, a wide variety of archaeal and bacterial taxa occurred in the benthic habitat. Although dead cyanobacterial cells originating from the water column rapidly sank to the water-sediment interface, SSU rRNA genes from cyanobacteria constituted an extremely minor fraction ( $2 \%$ of all sequences) in the benthic sediment (Fig. 6). Yan et al. (2017) reported that the decomposition of cyanobacterial cells produces nutrients (nitrate, phosphate, and organic substances) that may stimulate benthic microbial $\mathrm{CH}_{4}$ production. In addition, a positive relationship was clearly observed between the $\mathrm{CH}_{4}$ flux rate and productivity normalized to the chlorophyll $a$ concentration in freshwater environments (Beaulieu et al. 2019). Furthermore, Iwata et al. (2020) reported that the observed seasonal variation in meteorological and limnological environments from 2016 to 2017 indicated stable stratification (i.e., a difference in temperature between the surface and bottom layers) from May to September. These results suggested that the migration of microorganisms derived from the benthic sediment to planktonic cyanobacteria was not notable in the water column.

\section{Summary}

(1) We reported the first detection and concentration data of planktonic F430 in the water column by an ultrasmall-scale analysis $\left(\sim\right.$ femto mol g-wet $\left.{ }^{-1}\right)$, suggesting the potential occurrence of planktonic methanogen archaea. To support this feasibility study, we should consider a method optimization of DNA/RNA-based molecular analysis, such as the elimination of the sample matrix effect (e.g., extracellular polysaccharides stemming from massive cyanobacteria) with other precise analytical protocols (e.g., Wäge et al. 2020).

(2) SSU rRNA gene analysis revealed that the microbial communities differed dramatically between the water column and benthic sediment. After eventual detritus sinking, therefore, the planktonic primary producers contributed as a nutrient source to the benthic microbial habitat mostly at the water-sediment interface. 
Along with the short summary above, multiple novel chemical and microbial approaches are required to elucidate the issues associated with the methane paradox in water column environments.

\begin{abstract}
Abbreviations
F430: Coenzyme factor 430; HPLC: High-performance liquid chromatography; ESI-MS: Electrospray ionization-mass spectrometry; EIC: Extracted ion chromatography; MRM: Multiple reaction monitoring; DO: Dissolved oxygen; mcrA: Methyl coenzyme $M$ reductase A gene; OTU: Operational taxonomic unit; PCR: Polymerase chain reaction; SSU rRNA: Small subunit ribosome RNA; TN: Total nitrogen; TOC: Total organic carbon.
\end{abstract}

\section{Supplementary Information}

The online version contains supplementary material available at https://doi. org/10.1186/s40645-021-00450-7.

Additional file 1: Movie S1. Observation of lacustrine surface methane emission near the sampling site at Lake Suwa. The surface sediment has a large amount of $\mathrm{CH}_{4}$-rich gas because of microbial activity, including that of methanogenic archaea. This movie was taken at the present study site. Stimulation with a rod confirms that abundant bubbles are released from the surface sediment.

\section{Acknowledgements}

We express our sincere gratitude to Prof. W. B. Whitman (Univ. Georgia) for the constructive review and comments provided on the earlier version of the manuscript. The authors thank two anonymous reviewers for the valuable and critical comments, which helped to refine the initial manuscript. We thank the Research and Education Center for Inland Water Environments at Shinshu University for the provided assistance with our field survey. The authors thank Dr. Y. Isaji (JAMSTEC), Dr. Y.Takaki (JAMSTEC) and Prof. Y. Chikaraishi (Hokkaido Univ.) for their advice regarding lacustrine primary producers, SSU rRNA gene sequence analysis and chlorophyll profiles, as well as Prof. Y. Miyabara (Shinshu Univ.) for his knowledge of inland methane emissions and the planktonic flora in Lake Suwa. We thank Dr. N. Futatsugi (Shinshu Univ.) for an additional culture experiment. This study was conducted by the official collaboration agreement through the joint research project (FY2019-FY2021) between JAMSTEC (YT) and Shinshu University (HDP).

\section{Authors' contributions}

$A U, M M, N O$, and $Y T$ proposed the topic and designed the study framework. MK, YT and NO outlined the small-scale analytical development of F430 molecules in a decade. AU, MM, HDP, YT, and HI collected the samples. AU, $\mathrm{MM}, \mathrm{HI}, \mathrm{HDP}$, and $\mathrm{MO}$ performed the experiments. $\mathrm{AU}, \mathrm{MM}, \mathrm{HI}, \mathrm{MK}, \mathrm{NOO}, \mathrm{NO}$, and $Y T$ analyzed the samples and interpreted the results. AU and $Y T$ wrote the present report with contributions from NO and MM. All authors edited and approved the final manuscript.

\section{Funding}

This work was supported by KAKENHI grants from the Japan Society for the Promotion of Science (JSPS): 15H05332 (MK), 16H04083 (YT), 19H01005 (HI), 19H04261 (MK), $20 \mathrm{H00208} \mathrm{(NO),} \mathrm{and} \mathrm{20H02019(YT).}$

\section{Availability of data and materials}

Declaration of nucleotide sequence accession numbers: The SSU rRNA gene tag sequence data have been deposited in BioProject PRJNA 9444 under accession number DRA009781. The Global Lake and River Ice Phenology Database are compiled by the National Snow and Ice Data Center (NSIDC), Data Set https://doi.org/10.7265/N5W66HP8. The database of fixed point observations (temperature, dissolved oxygen, turbidity, live camera capture) in Lake Suwa is released by the project of Suwa Smart Society 5.0 at https:// sss50.harmonia-cloud.com. The other data sets supporting the conclusions drawn in this article are included within the article.

\section{Declarations}

\section{Competing interests}

The authors declare that the research was conducted in the absence of any commercial or financial relationships that could be construed as a potential conflict of interest.

\section{Author details}

${ }^{1}$ Biogeochemistry Research Center (BGC), Japan Agency for Marine-Earth Science and Technology (JAMSTEC), Yokosuka, Japan. ${ }^{2}$ Department of Science and Technology, Graduate School of Medicine, Science and Technology, Shinshu University, Matsumoto, Japan. ${ }^{3}$ Geological Survey of Japan (GSJ), National Institute of Advanced Industrial Science and Technology, Tsukuba, Japan.

${ }^{4}$ Department of Environmental Science, Faculty of Science, Shinshu University, Matsumoto, Japan. ${ }^{5}$ Institute for Extra-Cutting-Edge Science and Technology Avant-Garde Research (X-Star), JAMSTEC, Yokosuka, Japan.

Received: 24 April 2021 Accepted: 28 September 2021

Published online: 06 November 2021

\section{References}

Angel R, Matthies D, Conrad R (2011) Activation of methanogenesis in arid biological soil crusts despite the presence of oxygen. PLoS ONE 6:20453. https://doi.org/10.1371/journal.pone.0020453

Bastviken D, Ejlertsson J, Tranvik L (2002) Measurement of methane oxidation in lakes: a comparison of methods. Environ Sci Technol 36:3354-3361. https://doi.org/10.1021/es010311p

Bastviken D, Cole J, Pace M, Tranvik L (2004) Methane emissions from lakes: dependence of lake characteristics, two regional assessments, and a global estimate. Glob Biogeochem Cycles 18:GB4009. https://doi.org/10. 1029/2004GB002238

Batista AMM, Woodhouse JN, Grossart HP, Giani A (2019) Methanogenic archaea associated to Microcystis sp. in field samples and in culture. Hydrobiologia 831:163-172. https://doi.org/10.1007/s10750-018-3655-3

Beaulieu JJ, DelSontro T, Downing JA (2019) Eutrophication will increase methane emissions from lakes and impoundments during the 21st century. Nat Commun 10:1375. https://doi.org/10.1038/ s41467-019-09100-5

Berg A, Lindblad P, Svensson BH (2014) Cyanobacteria as a source of hydrogen for methane formation. World J Microbiol Biotechnol 30:539-545. https://doi.org/10.1007/s11274-013-1463-5

Bižic M, Klintzsch T, Ionescu D, Hindiyeh MY, Günthel M, Muro-Pastor AM, Eckert W, Urich T, Keppler F, Grossart HP (2020) Aquatic and terrestrial cyanobacteria produce methane. Sci Adv 6:eaax5343. https://doi.org/ 10.1126/sciadv.aax5343

Borrel G, Jézéquel D, Biderre-Petit C, Morel-Desrosiers N, Morel JP, Peyret P, Fonty G, Lehours AC (2011) Production and consumption of methane in freshwater lake ecosystems. Res Microbiol 162:832-847. https://doi. org/10.1016/j.resmic.2011.06.004

Buckles LK, Villanueva L, Weijers JWH, Verschuren D, Damste JSS (2013) Linking isoprenoidal GDGT membrane lipid distributions with gene abundances of ammonia-oxidizing Thaumarchaeota and uncultured crenarchaeotal groups in the water column of a tropical lake (Lake Challa, East Africa). Environ Microbiol 15:2445-2462. https://doi.org/10. $1111 / 1462-2920.12118$

Bukin SV, Pavlova ON, Kalmychkov GV, Ivanov VG, Pogodaeva TV, Galach'Yants YP, Bukin YS, Khabuev AV, Zemskaya TI (2018) Substrate specificity of methanogenic communities from Lake Baikal bottom sediments associated with hydrocarbon gas discharge. Microbiology 87:549-558. https://doi.org/10.1134/s0026261718040045

Burke RA, Reid DF, Brooks JM, Lavoie DM (1983) Upper water column methane geochemistry in the eastern tropical North Pacific. Limnol Oceanogr 28:19-32. https://doi.org/10.4319/lo.1983.28.1.0019

Caporaso JG, Kuczynski J, Stombaugh J, Bittinger K, Bushman FD, Costello EK, Fierer N, Peña AG, Goodrich JK, Gordon JI, Huttley GA, Kelley ST, Knights D, Koenig JE, Ley RE, Lozupone CA, McDonald D, Muegge BD, Pirrung M, Reeder J, Sevinsky JR, Turnbaugh PJ, Walters WA, Widmann J, Yatsunenko T, Zaneveld J, Knight R (2010) QIIME allows analysis 
of high-throughput community sequencing data. Nat Methods 7:335-336. https://doi.org/10.1038/nmeth.f.303

Chan OC, Claus P, Casper P, Ulrich A, Lueders T, Conrad R (2005) Vertical distribution of structure and function of the methanogenic archaeal community in Lake Dagow sediment. Environ Microbiol 7:1139-1149. https://doi.org/10.1111/j.1462-2920.2005.00790.x

Chen WM, Xie PB, Young CC, Sheu SY (2017) Formosimonas limnophila gen. nov., sp. nov., a new member of the family Burkholderiaceae isolated from a freshwater lake. Int J Syst Evol Microbiol 67:17-24. https://doi. org/10.1099/ijsem.0.001561

Cole JJ, Prairie YT, Caraco NF, McDowell WH, Tranvik LJ, Striegl RG, Duarte CM, Kortelainen P, Downing JA, Middelburg JJ, Melack J (2007) Plumbing the global carbon cycle: integrating inland waters into the terrestrial carbon budget. Ecosystems 10:172-185. https://doi.org/10. 1007/s10021-006-9013-8

Conrad R (2009) The global methane cycle: recent advances in understanding the microbial processes involved. Environ Microbiol Rep 1:285-292. https://doi.org/10.1111/j.1758-2229.2009.00038.x

Damm E, Helmke E, Thoms S, Schauer U, Nöthig E, Bakker K, Kiene RP (2010) Methane production in aerobic oligotrophic surface water in the central Arctic Ocean. Biogeosciences 7:1099-1108. https://doi.org/10. 5194/bg-7-1099-2010

de Angelis MA, Lee C (1994) Methane production during zooplankton grazing on marine phytoplankton. Limnol Oceanogr 39:1298-1308. https:// doi.org/10.4319/lo.1994.39.6.1298

Deutzmann JS, Stief P, Brandes J, Schink B (2014) Anaerobic methane oxidation coupled to denitrification is the dominant methane sink in a deep lake. Proc Natl Acad Sci 111:18273-18278. https://doi.org/10.1073/ pnas. 1411617111

Diekert G, Konheiser U, Piechulla K, Thauer RK (1981) Nickel requirement and factor F430 content of methanogenic bacteria. J Bacteriol 148:459-464. https://doi.org/10.1128/JB.148.2.459-464.1981

Donis D, Flury S, Stöckli A, Spangenberg JE, Vachon D, McGinnis DF (2017) Full-scale evaluation of methane production under oxic conditions in a mesotrophic lake. Nat Commun 8:1661. https://doi.org/10.1038/ s41467-017-01648-4

Dziallas C, Grossart HP (2012) Microbial interactions with the cyanobacterium Microcystis aeruginosa and their dependence on temperature. Mar Biol 159:2389-2398. https://doi.org/10.1007/s00227-012-1927-4

Edgar RC (2010) Search and clustering orders of magnitude faster than BLAST. Bioinformatics 26:2460-2461. https://doi.org/10.1093/bioinformatics/ bta461

Evans PN, Parks DH, Chadwick GL, Robbins SJ, Orphan VJ, Golding SD, Tyson GW (2015) Methane metabolism in the archaeal phylum Bathyarchaeota revealed by genome-centric metagenomics. Science 350:434-438. https://doi.org/10.1126/science.aac7745

Fernández JE, Peeters F, Hofmann H (2016) On the methane paradox: transport from shallow water zones rather than in situ methanogenesis is the major source of $\mathrm{CH}_{4}$ in the open surface water of lakes. J Geophys Res Biogeosci 121:2717-2726. https://doi.org/10.1002/2016jg003586

Gantner S, Andersson AF, Alonso-Sáez L, Bertilsson S (2011) Novel primers for 16S rRNA-based archaeal community analyses in environmental samples. J Microbiol Methods 84:12-18. https://doi.org/10.1016/j.mimet.2010.10. 001

Grossart HP, Frindte K, Dziallas C, Eckert W, Tang KW (2011) Microbial methane production in oxygenated water column of an oligotrophic lake. Proc Natl Acad Sci 108:19657-19661. https://doi.org/10.1073/pnas.11107 16108

Günthel M, Donis D, Kirillin G, Ionescu D, Bižic M, McGinnis DF, Grossart HP, Tang KW (2019) Contribution of oxic methane production to surface methane emission in lakes and its global importance. Nat Commun 10:5497. https://doi.org/10.1038/s41467-019-13320-0

Günthel M, Klawonn I, Woodhouse J, Bižić M, lonescu D, Ganzert L, Kümmel S, Nijenhuis I, Zoccarato L, Grossart HP (2020) Photosynthesis-driven methane production in oxic lake water as an important contributor to methane emission. Limnol Oceanogr 65:2853-2865. https://doi.org/10. 1002/Ino.11557

Han J, Jeon B-S, Park H-D (2012) Cyanobacteria cell damage and cyanotoxin release in response to alum treatment. Water Supply 12:549-555. https:// doi.org/10.2166/ws.2012.029
Hirai M, Nishi S, Tsuda M, Sunamura M, Takaki Y, Nunoura T (2017) Library construction from subnanogram DNA for pelagic sea water and deep-sea sediments. Microbes Environ 32:336-343. https://doi.org/10.1264/jsme2. ME17132

Holgerson MA, Raymond PA (2016) Large contribution to inland water $\mathrm{CO}_{2}$ and $\mathrm{CH}_{4}$ emissions from very small ponds. Nat Geosci 9:222-226. https:// doi.org/10.1038/ngeo2654

Inagaki F, Hinrichs K-U, Kubo Y, Bowles MW, Heuer VB, Hong W-L, Hoshino T, Ijiri A, Imachi H, Ito M, Kaneko M, Lever MA, Lin Y-S, Methé BA, Morita S, Morono Y, Tanikawa W, Bihan M, Bowden SA, Elvert M, Glombitza C, Gross D, Harrington GJ, Hori T, Li K, Limmer D, Liu C-H, Murayama M, Ohkouchi N, Ono S, Park Y-S, Phillips SC, Prieto-Mollar X, Purkey M, Riedinger N, Sanada Y, Sauvage J, Snyder G, Susilawati R, Takano Y, Tasumi E, Terada T, Tomaru H, Trembath-Reichert E, Wang DT, Yamada Y (2015) Exploring deep microbial life in coal-bearing sediment down to $\sim 2.5 \mathrm{~km}$ below the ocean floor. Science 349:420-424. https://doi.org/10.1126/science.aaa68 82

Isaji Y, Ogawa NO, Takano Y, Ohkouchi N (2020) Quantification and carbon and nitrogen isotopic measurements of heme $B$ in environmental samples. Anal Chem 92:11213-11222. https://doi.org/10.1021/acs.analchem.0c017 11

Itoh M, Kobayashi Y, Chen TY, Tokida T, Fukui M, Kojima H, Miki T, Tayasu I, Shiah FK, Okuda N (2015) Effect of interannual variation in winter vertical mixing on $\mathrm{CH}_{4}$ dynamics in a subtropical reservoir. J Geophys Res Biogeosci 120:1246-1261. https://doi.org/10.1002/2015jg002972

Iwata H, Hirata R, Takahashi Y, Miyabara Y, Itoh M, lizuka K (2018) Partitioning eddy-covariance methane fluxes from a shallow lake into diffusive and ebullitive fluxes. Bound-Layer Meteorol 169:413-428. https://doi.org/10. 1007/s10546-018-0383-1

Iwata H, Nakazawa K, Sato H, Itoh M, Miyabara Y, Hirata R, Takahashi Y, Tokida T, Endo R (2020) Temporal and spatial variations in methane emissions from the littoral zone of a shallow mid-latitude lake with steady methane bubble emission areas. Agric Meteorol 295:108184. https://doi.org/10.1016/j. agrformet.2020.108184

Kaneko M, Takano Y, Chikaraishi Y, Ogawa NO, Asakawa S, Watanabe T, Shima S, Kruger M, Matsushita M, Kimura H, Ohkouchi N (2014) Quantitative analysis of coenzyme F430 in environmental samples: a new diagnostic tool for methanogenesis and anaerobic methane oxidation. Anal Chem 86:3633-3638. https://doi.org/10.1021/ac500305j

Kaneko M, Takano Y, Ogawa NO, Sato Y, Yoshida N, Ohkouchi N (2016) Estimation of methanogenesis by quantification of coenzyme F430 in marine sediments. Geochem J 50:453-460. https://doi.org/10.2343/geochemj.2. 0410

Kaneko M, Takano Y, Kamo M, Morimoto K, Nunoura T, Ohkouchi N (2021) Insights into the methanogenic population and potential in subsurface marine sediments based on coenzyme F430 as a function-specific compound analysis. J Am Chem Soc Au. https://doi.org/10.1021/jacsau. $1 \mathrm{c00307}$

Khatun S, Iwata T, Kojima H, Fukui M, Aoki T, Mochizuki S, Naito A, Kobayashi A, Uzawa R (2019) Aerobic methane production by planktonic microbes in lakes. Sci Total Environ 696:133916. https://doi.org/10.1016/j.scitotenv. 2019.133916

Kim M, Shin B, Lee J, Park HY, Park W (2019) Culture-independent and culturedependent analyses of the bacterial community in the phycosphere of cyanobloom-forming Microcystis aeruginosa. Sci Rep 9:20416. https://doi. org/10.1038/s41598-019-56882-1

Kojima H, Tokizawa R, Kogure K, Kobayashi Y, Itoh M, Shiah FK, Okuda N, Fukui M (2014) Community structure of planktonic methane-oxidizing bacteria in a subtropical reservoir characterized by dominance of phylotype closely related to nitrite reducer. Sci Rep 4:5728. https://doi.org/10.1038/ srep05728

Li M, Nkrumah PN, Xiao M (2014) Biochemical composition of Microcystis aeruginosa related to specific growth rate: insight into the effects of abiotic factors. Inland Waters 4:357-362. https://doi.org/10.5268/IW-4.4.710

Li C, Hambright KD, Bowen HG, Trammell MA, Grossart HP, Burford MA, Hamilton DP, Jiang H, Latour D, Meyer El (2021) Global co-occurrence of methanogenic archaea and methanotrophic bacteria in Microcystis aggregates. Environ Microbiol. https://doi.org/10.1111/1462-2920.15691

Luton P, Wayne J, Sharp R, Riley P (2002) The mcrA gene as an alternative to $16 S$ rRNA in the phylogenetic analysis of methanogen populations in 
landfill. Microbiology 148:3521-3530. https://doi.org/10.1099/00221 287-148-11-3521

Magen C, Lapham LL, Pohlman JW, Marshall K, Bosman S, Casso M, Chanton JP (2014) A simple headspace equilibration method for measuring dissolved methane. Limnol Oceanogr Methods 12:637-650. https://doi.org/10. 4319/lom.2014.12.637

Mayr S, Latkoczy C, Krüger M, Günther D, Shima S, Thauer RK, Widdel F, Jaun B (2008) Structure of an F430 variant from archaea associated with anaerobic oxidation of methane. J Am Chem Soc 130:10758-10767. https://doi. org/10.1021/ja802929z

McGinnis DF, Kirillin G, Tang KW, Flury S, Bodmer P, Engelhardt C, Casper P, Grossart HP (2015) Enhancing surface methane fluxes from an oligotrophic lake: exploring the microbubble hypothesis. Environ Sci Technol 49:873-880. https://doi.org/10.1021/es503385d

Milkov AV, Sassen R (2002) Economic geology of offshore gas hydrate accumulations and provinces. Mar Petrol Geol 19:1-11. https://doi.org/10.1016/ S0264-8172(01)00047-2

Nakazato R, Hirabayashi K, Okino T (1998) Abundance and seasonal trend of dominant chironomid adults and horizontal distribution of larvae in eutrophic lake Suwa, Japan. Jpn J Limnol (rikusuigaku Zasshi) 59:443-455. https://doi.org/10.3739/rikusui.59.443

Naudts L, Greinert J, Artemov Y, Staelens P, Poort J, Van Rensbergen P, De Batist M (2006) Geological and morphological setting of 2778 methane seeps in the Dnepr paleo-delta, northwestern Black Sea. Mar Geol 227:177-199. https://doi.org/10.1016/j.margeo.2005.10.005

Nishiyama T, Ueki A, Kaku N, Ueki K (2009) Clostridium sufflavum sp. nov., isolated from a methanogenic reactor treating cattle waste. Int J Syst Evol Microbiol 59:981-986. https://doi.org/10.1099/ijs.0.001719-0

Nunoura T, Takaki Y, Kazama H, Hirai M, Ashi J, Imachi H, Takai K (2012) Microbial diversity in deep-sea methane seep sediments presented by SSU rRNA gene tag sequencing. Microbes Environ 27:382-390. https://doi. org/10.1264/jsme2.me12032

Ogawa NO, Nagata T, Kitazato H, Ohkouchi N (2010) Ultra-sensitive elemental analyzer/isotope ratio mass spectrometer for stable nitrogen and carbon isotope analyses. In: Ohkouchi N, Tayasu I, Koba K (eds) Earth, life and isotopes. Kyoto University Press, Kyoto, pp 339-353

Ohkouchi N, Takano Y (2014) Organic nitrogen: sources, fates, and chemistry, vol. 12, 10: organic geochemistry. In: Birrer B, Falkowski P, Freeman K (eds) Treatise on geochemistry. Elsevier, Amsterdam, pp 251-289. https://doi. org/10.1016/B978-0-08-095975-7.01015-9

Olenina I, Hajdu S, Edler L, Andersson A, Wasmund N, Busch S, Goebel J, Gromisz S, Huseby S, Huttunen M, Jaanus A, Kokkonen P, Ledaine I, Niemkiewicz E (2006) Biovolumes and size-classes of phytoplankton in the Baltic Sea. HELCOM Balt Sea Environ Proc 106:144

Oremland RS (1979) Methanogenic activity in plankton samples and fish intestines A mechanism for in situ methanogenesis in oceanic surface waters. Limnol Oceanogr 24:1136-1141. https://doi.org/10.4319/lo.1979. 24.6.1136

Park HD, Watanabe MF, Harada Kl, Suzuki M, Hayashi H, Okino T (1993) Seasonal variations of Microcystis species and toxic heptapeptide microcystins in Lake Suwa. Environ Toxicol Water Qual 8:425-435. https://doi.org/10. 1002/tox.2530080407

Park HD, Iwami C, Watanabe MF, Harada Kl, Okino T, Hayashi H (1998) Temporal variabilities of the concentrations of intra- and extracellular microcystin and toxic Microcystis species in a hypertrophic lake, Lake Suwa, Japan (1991-1994). Environ Toxicol Water Qual 13:61-72. https://doi.org/10. 1002/(sici) 1098-2256(1998)13:1\%3c61::Aid-tox4\%3e3.0.Co;2-5

Ploug H (2008) Cyanobacterial surface blooms formed by Aphanizomenon sp. and Nodularia spumigena in the Baltic Sea: small-scale fluxes, $\mathrm{pH}$, and oxygen microenvironments. Limnol Oceanogr 53:914-921. https://doi. org/10.4319/lo.2008.53.3.0914

Quast C, Pruesse E, Yilmaz P, Gerken J, Schweer T, Yarza P, Peplies J, Glöckner FO (2012) The SILVA ribosomal RNA gene database project: improved data processing and web-based tools. Nucleic Acids Res 41:D590-D596. https://doi.org/10.1093/nar/gks1219

Repeta DJ, Ferrón S, Sosa OA, Johnson CG, Repeta LD, Acker M, DeLong EF, Karl DM (2016) Marine methane paradox explained by bacterial degradation of dissolved organic matter. Nat Geosci 9:884-887. https://doi.org/10. 1038/ngeo2837

Reynolds CS (1987) Cyanobacterial water-blooms. In: Callow JA (ed) Advances in botanical research. Academic Press, London, pp 67-143
Ritt B, Sarrazin J, Caprais J-C, Noël P, Gauthier O, Pierre C, Henry P, Desbruyeres D (2010) First insights into the structure and environmental setting of cold-seep communities in the Marmara Sea. Deep Sea Res Part I Oceanogr Res 57:1120-1136. https://doi.org/10.1016/j.dsr.2010.05.011

Sakai S, Ehara M, Tseng IC, Yamaguchi T, Bräuer SL, Cadillo-Quiroz H, Zinder SH, Imachi H (2012) Methanolinea mesophila sp. nov., a hydrogenotrophic methanogen isolated from rice field soil, and proposal of the archaeal family Methanoregulaceae fam. nov. within the order Methanomicrobiales. Int J Syst Evol Microbiol 62:1389-1395. https://doi.org/10.1099/ijs.0. 035048-0

Sasakawa M, Tsunogai U, Kameyama S, Nakagawa F, Nojiri Y, Tsuda A (2008) Carbon isotopic characterization for the origin of excess methane in subsurface seawater. J Geophys Res 113:C03012. https://doi.org/10.1029/ 2007JC004217

Schirmack J, Mangelsdorf K, Ganzert L, Sand W, Hillebrand-Voiculescu A, Wagner D (2014) Methanobacterium movilense sp. nov., a hydrogenotrophic, secondary-alcohol-utilizing methanogen from the anoxic sediment of a subsurface lake. Int I Syst Evol Microbiol 64:522-527. https://doi.org/10. 1099/ijs.0.057224-0

Schmale O, Wäge J, Mohrholz V, Wasmund N, Gräwe U, Rehder G, Labrenz M, Loick-Wilde N (2018) The contribution of zooplankton to methane supersaturation in the oxygenated upper waters of the central Baltic Sea. Limnol Oceanogr 63:412-430. https://doi.org/10.1002/Ino.10640

Sørensen K, Řeháková K, Zapomělová E, Oren A (2009) Distribution of benthic phototrophs, sulfate reducers, and methanogens in two adjacent saltern evaporation ponds in Eilat, Israel. Aquat Microb Ecol 56:275-284. https:// doi.org/10.3354/ame01307

Springer E, Sachs MS, Woese CR, Boone DR (1995) Partial gene sequences for the A subunit of methyl-coenzyme M reductase ( $\mathrm{mcr}$ ) as a phylogenetic tool for the family Methanosarcinaceae. Int J Syst Bacteriol 45:554-559. https://doi.org/10.1099/00207713-45-3-554

Steinberg LM, Regan JM (2008) Phylogenetic comparison of the methanogenic communities from an acidic, oligotrophic fen and an anaerobic digester treating municipal wastewater sludge. Appl Environ Microbiol 74:6663-6671. https://doi.org/10.1128/aem.00553-08

Suwa Construction Office (2019) Lake bottom survey of Lake Suwa. Lake Suwa Vision Promotion Conference, Nagano Pref

Takano Y, Kaneko M, Kahnt J, Imachi H, Shima S, Ohkouchi N (2013) Detection of coenzyme F430 in deep sea sediments: a key molecule for biological methanogenesis. Org Geochem 58:137-140. https://doi.org/10.1016/j. orggeochem.2013.01.012

Tang KW, McGinnis DF, Ionescu D, Grossart HP (2016) Methane production in oxic lake waters potentially increases aquatic methane flux to air. Environ Sci Technol Lett 3:227-233. https://doi.org/10.1021/acs.estlett.6b00150

Tarnovetskii IY, Merkel AY, Kanapatskiy TA, Ivanova EA, Gulin MB, Toshchakov S, Pimenov NV (2018) Decoupling between sulfate reduction and the anaerobic oxidation of methane in the shallow methane seep of the Black sea. FEMS Microbiol Lett. https://doi.org/10.1093/femsle/fny235

Tayasu I, Hirasawa R, Ogawa NO, Ohkouchi N, Yamada K (2011) New organic reference materials for carbon- and nitrogen-stable isotope ratio measurements provided by Center for Ecological Research, Kyoto University, and Institute of Biogeosciences, Japan Agency for Marine-Earth Science and Technology. Limnology 12:261-266. https://doi.org/10.1007/ s10201-011-0345-5

Thauer RK, Kaster A-K, Seedorf H, Buckel W, Hedderich R (2008) Methanogenic archaea: ecologically relevant differences in energy conservation. Nat Rev Microbiol 6:579-591. https://doi.org/10.1038/nrmicro1931

Urai A, Takano Y, Imachi H, Ishii S, Matsui Y, Ogawara M, Tasumi E, Miyairi Y, Ogawa ON, Yoshimura T, Inagaki F, Yokoyama Y, Kawano K, Murai D, Park HD, Ohkouchi N (2021) Origin of deep methane associated with a unique community of microorganisms in an organic- and iodine-rich aquifer. ACS Earth Space Chem 5:1-11. https://doi.org/10.1021/acsearthspacech em.0c00204

Valentine DL (2011) Emerging topics in marine methane biogeochemistry. Ann Rev Mar Sci 3:147-171. https://doi.org/10.1146/annur ev-marine-120709-142734

Vu HTL, Yukphan P, Bui VTT, Charoenyingcharoen P, Malimas S, Nguyen LK, Muramatsu Y, Tanaka N, Tanasupawat S, Le BT, Nakagawa Y, Yamada Y (2019) Acetobacter sacchari sp. nov., for a plant growth-promoting acetic acid bacterium isolated in Vietnam. Ann Microbiol 69:1155-1163. https:// doi.org/10.1007/s13213-019-01497-0 
Wäge J, Schmale O, Labrenz M (2020) Quantification of methanogenic Archaea within Baltic Sea copepod faecal pellets. Mar Biol 167:1-7. https://doi.org/10.1007/s00227-020-03759-x

Wang H, Lu J, Wang W, Yang L, Yin C (2006) Methane fluxes from the littoral zone of hypereutrophic Taihu Lake, China. J Geophys Res Atmos 111:D17. https://doi.org/10.1029/2005jd006864

Wang Q, Dore JE, McDermott TR (2017) Methylphosphonate metabolism by Pseudomonas sp. populations contributes to the methane oversaturation paradox in an oxic freshwater lake. Environ Microbiol 19:2366-2378. https://doi.org/10.1111/1462-2920.13747

Watanabe K, Park HD, Kumon F (2012) Historical change of phytoplankton in a eutrophic lake in Japan as determined by analysis of photosynthetic pigments in a lakebed sediment core. Environ Earth Sci 66:2293-2300. https://doi.org/10.1007/s12665-011-1452-7

Watanabe T, Miura A, Iwata T, Kojima H, Fukui M (2017) Dominance of Sulfuritalea species in nitrate-depleted water of a stratified freshwater lake and arsenate respiration ability within the genus. Environ Microbiol Rep 9:522-527. https://doi.org/10.1111/1758-2229.12557

Xu S, Sun Q, Zhou X, Tan X, Xiao M, Zhu W, Li M (2016) Polysaccharide biosynthesis-related genes explain phenotype-genotype correlation of Microcystis colonies in Meiliang Bay of Lake Taihu, China. Sci Rep 6:35551. https://doi.org/10.1038/srep35551

Yamada T, Sekiguchi Y, Hanada S, Imachi H, Ohashi A, Harada H, Kamagata Y (2006) Anaerolinea thermolimosa sp. nov., Levilinea saccharolytica gen. nov., sp. nov. and Leptolinea tardivitalis gen. nov., sp. nov., novel filamentous anaerobes, and description of the new classes Anaerolineae classis nov. and Caldilineae classis nov. in the bacterial phylum Chloroflexi. Int J Syst Evol Microbiol 56:1331-1340. https://doi.org/10.1099/ijs.0.64169-0

Yan X, Xu X, Wang M, Wang G, Wu S, Li Z, Sun H, Shi A, Yang Y (2017) Climate warming and cyanobacteria blooms: looks at their relationships from a new perspective. Water Res 125:449-457. https://doi.org/10.1016/j. watres.2017.09.008
Yoshida T, Yuki Y, Lei S, Chinen H, Yoshida M, Kondo R, Hiroishi S (2003) Quantitative detection of toxic strains of the cyanobacterial genus Microcystis by competitive PCR. Microb Environ 18:16-23. https://doi.org/10.1264/ jsme2.18.16

Yoshioka T, Wada E, Saijo Y (1988) Isotopic characterization of lake Kizaki and lake Suwa. Jpn J Limnol 49:119-128. https://doi.org/10.3739/rikusui.49. 119

Yoshioka T, Wada E, Hayashi H (1994) A stable isotope study on seasonal food web dynamics in a eutrophic lake. Ecology 75:835-846. https://doi.org/ $10.2307 / 1941739$

Zepp Falz K, Holliger C, Großkopf R, Liesack W, Nozhevnikova AN, Müller B, Wehrli B, Hahn D (1999) Vertical distribution of methanogens in the anoxic sediment of Rotsee (Switzerland). Appl Environ Microbiol 65:2402-2408. https://doi.org/10.1128/aem.65.6.2402-2408.1999

Zhang J, Kobert K, Flouri T, Stamatakis A (2014) PEAR: a fast and accurate Illumina Paired-End reAd mergeR. Bioinformatics 30:614-620. https://doi. org/10.1093/bioinformatics/btt593

Zhou Z, Pan J, Wang F, Gu JD, Li M (2018) Bathyarchaeota: globally distributed metabolic generalists in anoxic environments. FEMS Microbiol Rev 42:639-655. https://doi.org/10.1093/femsre/fuy023

Zhou Z, Liu Y, Lloyd KG, Pan J, Yang Y, Gu JD, Li M (2019) Genomic and transcriptomic insights into the ecology and metabolism of benthic archaeal cosmopolitan, Thermoprofundales (MBG-D archaea). ISME J 13:885-901. https://doi.org/10.1038/s41396-018-0321-8

\section{Publisher's Note}

Springer Nature remains neutral with regard to jurisdictional claims in published maps and institutional affiliations.

\section{Submit your manuscript to a SpringerOpen ${ }^{\circ}$ journal and benefit from:}

- Convenient online submission

- Rigorous peer review

- Open access: articles freely available online

- High visibility within the field

- Retaining the copyright to your article

Submit your next manuscript at $\boldsymbol{\nabla}$ springeropen.com 